\title{
ArcheoSciences
}

Revue d'archéométrie

$40 \mid 2016$

Varia

\section{Multi-method dating of Grimaldi castle foundations in Antibes, France}

Étude chronologique multi-méthode des soubassements du château Grimaldi à Antibes, France

Petra Urbanova, Eric Delaval, Philippe Lanos, Pierre Guibert, Philippe Dufresne, Claude Ney, Robert Thernot and Philippe Mellinand

\section{(2) OpenEdition}

Journals

Electronic version

URL: https://journals.openedition.org/archeosciences/4702

DOI: 10.4000/archeosciences.4702

ISBN: 978-2-7535-5384-2

ISSN: 2104-3728

Publisher

Presses universitaires de Rennes

Printed version

Date of publication: 30 December 2016

Number of pages: 17-33

ISBN: 978-2-7535-5382-8

ISSN: 1960-1360

\section{Electronic reference}

Petra Urbanova, Eric Delaval, Philippe Lanos, Pierre Guibert, Philippe Dufresne, Claude Ney, Robert Thernot and Philippe Mellinand, "Multi-method dating of Grimaldi castle foundations in Antibes, France", ArcheoSciences [Online], 40 | 2016, Online since 30 December 2018, connection on 27 February 2022. URL: http://journals.openedition.org/archeosciences/4702 ; DOI: https://doi.org/ 10.4000/archeosciences.4702 


\title{
Multi-method dating of Grimaldi Castle Foundations in Antibes, France
}

\author{
Étude chronologique multi-méthode des soubassements \\ du château Grimaldi à Antibes, France
}

\author{
Petra Urbanováa, Eric Delaval ${ }^{b}$, Philippe $\operatorname{Lanos}^{c}$, Pierre Guibert ${ }^{a}$, \\ Philippe Dufresne ${ }^{c}$, Claude $\mathrm{NeY}^{\mathrm{a}}$ et Robert Thernot ${ }^{\mathrm{d}}$ \\ avec la collaboration de Philippe MeLLINAND ${ }^{\mathrm{e}}$
}

\begin{abstract}
The foundations of Grimaldi castle in Antibes belonged originally to a vast monumental edifice of an unknown origin. No historical records that would allow establishing precise chronological framework of this building exist. Therefore, four approaches were combined in order to date its construction: relative chronology from archaeology with "physical" dating methods applied on building materials, e.g. archaeomagnetic dating of bricks and dating of mortars by optically stimulated luminescence using both the single grain and the multigrain technique. Whereas archaeomagnetic dating followed a well-established, reliable measurement protocol, dating of archaeological mortar by optically stimulated luminescence using the single grain technique represents quite new, exploratory approach that allows direct dating of the moment of edification. Luminescence dating showed that mortars were well bleached. Variations of the dose rate due to the heterogeneous distribution of radioelements in the matrix were observed. In the given context, none of the four approaches used would succeed to date the construction of the remains with certainty if they were used separately. Nevertheless, thanks to the mutual comparison of dating results, a reliable chronology have been established. The obtained results are in agreement and suggest the Grimaldi castle foundations were built between the second half of the first century and the second century A.D. Our interdisciplinary approach thus proves ancientness of the standing masonry and attests cultural and historical significance of the monument.
\end{abstract}

Résumé : Les soubassements du château Grimaldi à Antibes appartiennent aux vestiges d'un monument romain dont la nature n'est pas connue. Aussi, il n'existe aucune source historique qui permettrait d'établir la chronologie précise de ce bâtiment. Ainsi, quatre approches ont été combinées pour dater sa construction: chronologie relative de l'étude archéologique, datation des terres cuites par archéomagnétisme et datation des mortiers par luminescence optiquement stimulée en utilisant les techniques de monograin et de multigrain. La datation par archéomagnétisme a suivi un protocole de mesure bien établi et fiable. La datation des mortiers par luminescence optiquement stimulée monograin représente une approche nouvelle et exploratoire, permettant de dater directement le moment de l'édification de la maçonnerie. Ces analyses ont révélé un bon degré de blanchiment des mortiers étudiés. Quelques variations du débit de dose due à la distribution hétérogène des radioéléments dans la matrice des échantillons ont été observées. Dans un contexte comme celui du château Grimaldi, aucune des approches mentionnées n'aurait réussi de dater la construction des vestiges avec une certitude s'elles avaient été utilisées séparément. Néanmoins, grâce aux comparaisons mutuelles des résultats de datation, nous avons pu établir une chronologie fiable. Les résultats obtenus par ces différentes approches sont cohérents et proposent la construction des soubassements du château Grimaldi entre la seconde moitié du premier et le deuxième siècle de notre ère. Notre travail interdisciplinaire confirme ainsi l'ancienneté de la maçonnerie en élévation et atteste l'importance patrimoniale et historique de ce monument.

${ }^{a}$ IRAMAT-CRP2A, Institut de Recherche sur les ArchéoMATériaux - Centre de Recherche en Physique Appliquée à l'Archéologie, UMR 5060 CNRSUniversité de Bordeaux-Montaigne, Maison de l'Archéologie, Esplanade des Antilles, 33607 PESSAC cedex, France. (Petra.Urbanová@u-bordeauxmontaigne.fr)

${ }^{b}$ Musée d'archéologie d'Antibes, Bastion Saint-André, 06600 AnTIBES, France.

'IRAMAT-CRP2A, Institut de Recherche sur les ArchéoMATériaux - Centre de Recherche en Physique Appliquée à l'Archéologie, Géosciences-Rennes, UMR 6118 Université Rennes 1, Campus de Beaulieu, Bât. 15, CS 74205 - 35042 RENNES cedex, France.

"Inrap/Archéologie des Sociétés Méditerranéennes - UMR 5140, Centre archéologique Inrap, 105 rue Serpentine, 13510 EGUILLES, France.

e Inrap/Centre Camille Jullian. UMR 7299, Centre archéologique Inrap, 105, rue Serpentine, 13510 EGUILLES, France. 
Keywords: archaeomagnetism, brick, construction, mortar, optically stimulated luminescence, single grain technique.

Mots-clés : archaéomagnétisme, brique, construction, mortier, luminescence stimulée optiquement, technique de monograin.

\section{INTRODUCTION}

\section{Presentation of the archaeological site}

Antibes is a French municipality situated in the AlpesMaritimes department in the Provence-Alpes-Côte d'Azur region at the Mediterranean seashore, $205 \mathrm{~km}$ from Marseille in the east and $23 \mathrm{~km}$ from Nice in the south-west. First traces of an organized human settlement appear in the Early Iron Age with a dwelling implanted in the Rocher (the rock cliff in the actual city center). The foundation of the Antipolis colony is closely related to the expansion of Greeks from Marseille in the $4^{\text {th }}$ century B.C. The Greek town was probably set at the foot of the Antibes cliff under the actual city.

The Grimaldi castle, known these days for the famous Picasso art collection, was built in the Middle-Ages at the top of the Rocher suceeding a vast monumental edifice from the Gallo-Roman period. The foundations of the castle (Figure 1, Figure 2a), faced with quarried stones and bricks visible at a height of several meters, belonged to this monument of an unknown origin. In order to determine the date of the construction of this monument, the part of the foundations was subjected to an archaeometric study within an archaeological research programme (PCR 2011-2013) Antipolis, des origines au royaume des Francs directed by Eric Delaval, M. Bats, L. Mercuri and R. Thernot.

\section{Archaeological background}

The dating of the Grimaldi castle foundations is based on the archaeological hypotheses that emerged from archaeological sondages realized on the square located in the west flank of the castle under the supervision of Philippe Mellinand (INRAP; Mellinand et al. 2007).

During these excavations in 2007, the archaeologists focused on the foundation fosse of the west perimeter wall MR10002 belonging to the same construction phase as the parallel wall MR10003 (Figure 1). These two walls formed a vaulted gallery. The width of the foundation fosse of the wall MR10002, which was dug into the rock, is identical to the width of the masonry and thus did not have to be filled up. However, this fosse crosses over a circular pit dug into the rock at the same place before the construction of the masonry. Prior to the erection of the castle foundations, the pit was cleaned out and it was filled up with construction mortar in the bottom level and with clay sediment in the upper level. The sediment contained nine ceramic shards, gravels, charcoals and plaster fragments. One of the shards was precisely dated as the fragment of south-Gallic terra sigillata (type Drag-37a, study realized by Emmanuel Pellegrino) which characterizes the period 60-100 A.D.

Since it does not seem likely that the circular pit remained uncovered or that it was cleaned and filled up again after the construction of the masonry, the terminus post quem of this stratigraphic unit containing the shards is the last third of the $1^{\text {st }}$ century A.D. That is also the terminus post quem of the construction of the Gallo-Roman monument, the remains of which correspond to the Grimaldi castle foundations.

Above the backfilled circular fosse, three stratigraphic units are visible in the following order: the homogeneous backfilling layer covering the fosse and supporting the wall, another backfilling layer and an artificial ground level. The dating of these stratigraphic units indicates the period between $17^{\text {th }}$ and $18^{\text {th }}$ century.

\section{Objectives of the study}

The small number of found shards as well as the chronological hiatus happening in the stratigraphy casts doubt on the archaeological interpretations. Therefore, archaeometric analyses of construction materials were performed in order to support the hypotheses on the established chronology. Two physical methods were employed with the following objectives:

- to date the construction of the foundation wall MR 10003 by means of archaeomagnetic dating (AM) of bricks assuming that the bricks originated from the original structure and have been used shortly after their making;

- to date archaeological mortars by optically stimulated luminescence using the single grain technique (SG-OSL).

Whereas the AM dating approach followed a well-established, reliable measurement protocol (e.g. Lanos, 1998), the dating of archaeological mortar by SG-OSL represents a new, innovative and exploratory approach. A development of 
Figure 1: (See colour plate II) Plan of the Gallo-Roman masonries observed at Grimaldi Castle (in red). Topographical ground Ville d'Antibes, record of the castle Albéric Olivier CNRS, topography Laurent Vallières Inrap. Figure 1 : (Voir planche couleur II) Plan des structures antiques observées dans le château Grimaldi (en rouge). Fond topographique Ville d'Antibes, relevé du château Albéric Olivier CNRS, topographie Laurent Vallières Inrap.

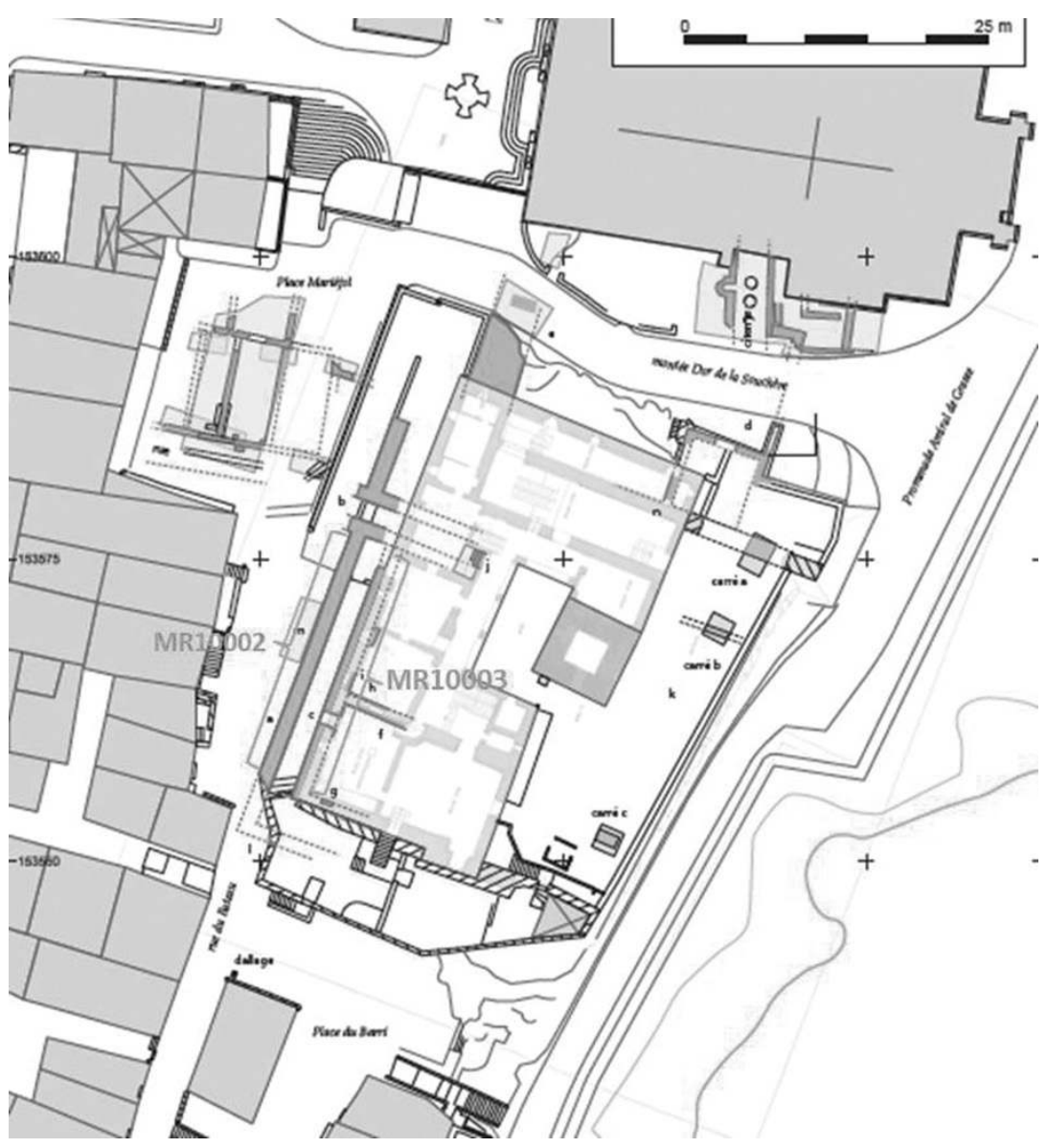

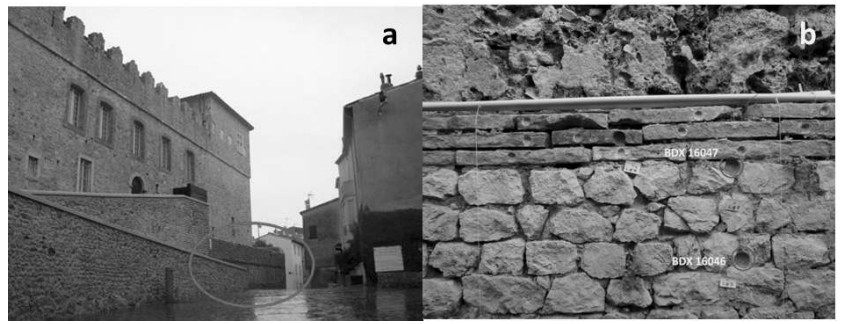

Figure 2: (See colour plate II) a) View on the west face of the castle, the gallo-roman foundations marked in a red circle; b) Wall MR 10003 after sampling of both bricks and mortars, before restoration.

Figure 2: (Voir planche couleur II) a) Vue extérieure du château, face ouest avec des soubassements gallo-romains (cercle rouge); b) Mur MR 10003 après l'échantillonnage des briques et des mortiers, avant la restauration.

this new application was part of the $\mathrm{PhD}$. research resulting in several publications (Urbanová et al., 2015; Urbanová \& Guibert, in press) where its principles are described and its significance explained. The originality and the significance of dating archaeological mortar by SG-OSL consist in the possibility to date directly the moment of the edification of the masonry by means of dating the last exposure of sand grains in mortar aggregate to daylight. Contrary to dating of bricks, the risks of potential re-use of construction materials (e. g. Guibert et al., 2012) are eliminated when dating the mortar, since the latter can only be used fresh during the building process.

\section{Materials AND METHOdS}

\section{Sampling}

During the sampling campaign that took place in 2012, five fragments of bedding mortar for luminescence dating and 92 brick pieces for archaeomagnetic dating were sampled. All elements were taken from the wall MR 10003 using a core drill designed for wet cutting with a $50 \mathrm{~mm}$ diameter coring auger for mortars and a $25 \mathrm{~mm}$ diameter one for bricks. As visible in the Figure $2 b$, mortars come from different levels of the masonry, whereas all the bricks originate from the course located $205 \mathrm{~cm}$ above the actual 
ground. In 2014, the sampled spots were filled with repair mortar, whose external parts were colored by mineral oxides in order to mask the intervention.

\section{Dating of bricks by archaeomagnetism (AM)}

The archaeomagnetic dating method is based on the ability of baked clay to acquire a thermoremanent magnetization (TRM) during the cooling process following heating above the so called Curie temperatures (up to $680^{\circ} \mathrm{C}$ ) of magnetic carriers in the clay. Hence, baked clay fossilizes the direction and the intensity of the ambient geomagnetic field for a particular geographical location in the form of a very stable magnetization. The direction is represented by its inclination (I) versus the local horizontal plane and by its declination (D), the angle between the Magnetic North and the Geographical North. The magnetization intensity (F) acquired is proportional to the geomagnetic field intensity which is expressed in micro-tesla $(\mu \mathrm{T})$.

The parallelism between the acquired magnetization and the ambient geomagnetic field and the fields variation in intensity and in direction over time are the bases of the archaeomagnetic dating method. If the variation curve of the direction is known on the grounds of a number of well dated archaeological materials prior to the measurement, it is then possible to date the last firing of baked clay. The date of the last firing is obtained by transferring the determined mean inclination and declination values after the latitude correction on the reference secular variation curve of the past geomagnetic field.

When a in situ structure (kiln, oven...) is studied, the three geomagnetic characteristics can be restored. This is not the case of displaced material such as bricks. Indeed, these building materials were removed from the original place of their manufacture and transferred to the building site. This displacement means a definitive loss of the geographic coordinates (North, East, Vertical) in which the bricks were fired. However, it is reasonable to assume that a rectilinear object would preferentially lie on one of its flat sides during firing: on flat, upright or on (long) edge. Given that the floor of the kiln is more likely to be horizontal and smooth, the horizontal plane may be conserved as one of the three planes which constitute the basic trihedral system of the object. In practice, the magnetisation direction is determined for each of the three firing positions on flat, on edge or upright. As the secular variation of the inclination varies between 45 and $75^{\circ}$ in France during the historical period, we may select from the three possible positions the one which gives an inclination within an enlarged interval $45^{\circ}$ to $90^{\circ}$ (Lanos, 1987, 1994, 1998 and 1999): the solution is to all intents and purposes unequivocal, provided that the latitude of the firing site is greater than $35^{\circ}$ (North or South). It has to be specified that the declination cannot be determined. However, it is possible to characterize the orientation of the vertical plane of the brick with respect to the magnetic north at the date of firing. This angle is called "deviation". It represents the angle between the vertical flattening plane of the brick and the magnetic north indicated by the magnetization vector, for the selected firing position. The declination between this magnetic north direction and the geographic north remains unknown. The deviation lies between $-90^{\circ}$ and $+90^{\circ}$.

A set of displaced materials (tiles, bricks, paving tiles) can be statistically processed by archaeomagnetism if it is composed of at least a hundred different objects originating from a single "archaeomagnetic unit" (firing at the same date in the same archaeological entity). Such a number is necessary in order to compensate positioning errors of the bricks along the vertical in the kiln. Observations during excavation are essential to detect a possible mixing of the material or a reuse of materials of different origins.

\section{Dating of mortars by optically stimulated luminescence (OSL)}

The principle of OSL dating is discussed in a number of publications (Aitken, 1998; Wintle, 2008). The OSL age of a sample is calculated as a ratio of an average archaeological dose (also called "paleodose" for old samples) to annual dose rate. The specificity of the present study lies in the analyses of quartz grains extracted from mortar that were performed exclusively with the single grain technique (SG-OSL; Duller \& Murray, 2000; Duller, 2008) in order to overcome the problems of heterogeneous bleaching and therefore to avoid the age overestimation (as observed during previous attempts: Goedicke, 2003 and 2011, Panzeri, 2013; Urbanová, et al., 2015).

\section{OSL sample preparation}

The mortar preparation for OSL and gamma spectrometry measurements has been discussed in detail in previous publications (Urbanová et al., 2015; Urbanová \& Guibert, in press). We remind briefly the basics. $2-\mathrm{mm}$ thick outer surface of the core drills was removed using a water-lubricated diamond saw. The internal part of the core drills was crushed. One part of the powder obtained was taken to prepare sealed tubes for gamma spectrometry measurements whereas the other part was submitted to chemical treatments resulting in the extraction of the $200-250 \mu \mathrm{m}$ size quartz used for the SG-OSL analyses. The compact parts of the 
studied samples were used to prepare thin and thick sections for material characterization.

\section{OSL instrumentation, measurements and data evaluation}

All OSL measurements were performed using a TL/ OSL DA20 Risø reader. The light detection system of the reader consists of an EMI Q9235 photomultiplier tube and $7.5 \mathrm{~mm}$ of Hoya U-340 filter for detection in the UV-blue wavelength range (about $280-370 \mathrm{~nm}$ ). A ${ }^{90} \mathrm{Sr} /{ }^{90} \mathrm{Y}$ beta source was used as an irradiation source (dose rate $0.150 \pm 0.005 \mathrm{mG} / \mathrm{s}$ ). Two different luminescence stimulation systems depending on the measurement protocol were used. The OSL measurements following a standard multigrain technique use Blue LEDs (NISHIA type NSPB-500s) with a peak emission at $470 \mathrm{~nm}$ for the stimulation, while a single grain analyses was performed with a $10 \mathrm{mV} \mathrm{Nd}$ : $\mathrm{YVO}_{4}$ solid state diode-pumped laser emitting at $532 \mathrm{~nm}$. The total dissolution of feldspar in the etched fractions from mortars was verified before the dating procedure by IRSL test on multigrain discs (described in Urbanová et al., 2015). The measurements of recovery dose and archaeological doses were realized applying the SAR protocol (Murray $\&$ Wintle, 2000) with the regeneration doses 4.8, 9.6, 14.4, 19.2, 0 , $4.8 \mathrm{~Gy}$, the preheat and cut-heat temperatures of $240^{\circ} \mathrm{C}$ et $190^{\circ} \mathrm{C}$, respectively, and the recovery dose $4.8 \mathrm{~Gy}$.

OSL signals from the multi-grain aliquots are based on the summation of the first $0.8 \mathrm{~s}$ of stimulation corrected for background derived from the last $8 \mathrm{~s}$ (time of stimulation: 40s). The single-grain OSL signals are derived from the summation of the first $0.05 \mathrm{~s}$ of stimulation less the sum of the last $0.2 \mathrm{~s}$ (time of stimulation: $1 \mathrm{~s}$ ). For each grain or disc, the sensitivity-corrected regenerated OSL signals $\left(\mathrm{L}_{\mathrm{x}} / \mathrm{T}_{\mathrm{x}}\right)$ were fitted with an exponential function and each individual archaeological dose $\left(D_{e}\right)$ was estimated by projecting the sensitivity-corrected natural signal $\left(\mathrm{L}_{\mathrm{N}} / \mathrm{T}_{\mathrm{N}}\right)$ onto the fitted curve. The standard error on the individual archaeological dose was obtained by Analyst version 4.11 from counting statistics, curve fitting and the instrumental reproducibility error of $2.7 \%$ (the value calculated from the series of measurements performed in the IRAMAT-CRPAA laboratory in Bordeaux). For more details and the discussion concerning the experimental parameters and data evaluation, the reader can refer to thepublications on this topic related directly to this study (Urbanová et al., 2015; Urbanová \& Guibert, in press) or to other studies on young samples (Thomsen et al., 2005; Panzeri, 2013; Sim et al., 2014; Medialdea et al., 2014).

\section{Dose rate determination, scanning electron microscopy and beta-imaging}

The practical aspects and the measurement details on all the below-mentioned analyses are described in Urbanová et al. (2015). Contributions of the different dose rate components used for the age calculation were measured. The contribution of sample matrix was determined by low background gamma spectrometry that allows obtaining $\mathrm{K}$, $\mathrm{U}$ and Th contents of dated material, converted into the related dose rates using the conversion factors published by Guérin et al. (2011). The environmental contribution was measured by $\mathrm{Al}_{2} \mathrm{O}_{3}: \mathrm{C}$ dosimetry. Internal radioactivity of the quartz grains used for dating was evaluated by inductively coupled plasma mass spectrometry (ICP-MS). Distributions of $\beta$ emitting minerals within mortar matrix were mapped by beta-imaging system. A scanning electron microscopy coupled with an energy dispersive X-ray analysis spectrometer (SEM-EDX) was used for mapping the potassium content in the different zones of mortar matrix as described in Urbanová et al. (2015).

An approximate contribution of water content to the annual dose rate was estimated from the difference in the weight between the dry sample and the same sample saturated with water, assuming $50 \%$ of the saturation value for the masonry. The standard deviation on estimated water content was taken equal to $29 \%$.

\section{RESULTS AND DISCUSSION}

\section{Dating of bricks by archaeomagnetism}

\section{Sampling on the field and specimen preparation}

From 94 bricks within the wall MR 10003, $-5 \mathrm{~cm}$ long cores were taken using a portable, water cooled, hand-held drill. The field sampling method involved drawing a line parallel to the long edge of the brick (ox axis) with a carbide needle. Samples were drilled so their axis was perpendicular to this line and parallel to the plane of the bricks inserted in the wall. In the laboratory, these cores were cut to $10.8 \mathrm{~cm}^{3}$ cores with a diameter of $25 \mathrm{~mm}$ and a length of $22 \mathrm{~mm}$. Thus, a local coordinate system is attached to each specimen: ox axis along the long edge, oy axis perpendicular to the flattening plane of the brick, oz axis along the short edge of the brick (which goes inwardly of the wall, in situ). Each specimen is referred to by a core number (1 to 94), a letter (B for brick) and a specimen number (1 or 2 ): for instance $40 \mathrm{~B} 1$. 
Magnetic measurements, demagnetization and anisotropy correction

Magnetization measurements have been carried out in Rennes Laboratory using the "Molspin" spinner magnetometer. Thermal demagnetizations in zero field and TRM anisotropy determinations have been performed using the MMTD oven (Magnetic Measurements). Low field susceptibility was measured after each heating step using a Bartington MS2 susceptibility-meter (Bartington instruments) in order to monitor mineralogical changes during heatings.

Detailed stepwise thermal demagnetization (at 100, 150, $200,250,300,350,400,450$ and $500^{\circ} \mathrm{C}$ ) was performed on the first 36 specimens to identify if they contain one or two components of magnetization. As seen in Figure 3, all of the specimens present only one magnetization component which corresponds to the manufacture of the bricks. We consider this is also the case for the rest of the specimens.

The TRM anisotropy tensor was determined on the same 36 specimens following the procedure described by Chauvin et al. Four successive heating steps at $450^{\circ} \mathrm{C}$ were performed with a laboratory field of $60 \mu \mathrm{T}$ applied along the $+\mathrm{Z},+\mathrm{X},+\mathrm{Y}$ axis of each specimen. A thermal stability check along the
$+\mathrm{Z}$ axis was also performed. The alteration factor $(0.6 \%$ in average) determined via the stability check is much less than $5 \%$ for the anisotropy correction to be applied. The principal axes of anisotropy ellipsoids show that the anisotropy is quite oblate and correlated to the shape of the bricks. Samples were then individually corrected for anisotropy using the mean Eigenvalues:

$$
\mathrm{F} 13=1.077 \quad \mathrm{~F} 12=1.030 \quad \mathrm{~F} 23=1.046
$$

\section{Statistical analysis of the TRM}

Magnetic measurements and thermal demagnetizations showed that the set of bricks is homogeneous. The bricks were produced at the same date and in the same place. The magnetization directions of the 94 specimens can thus be directly related to the geomagnetic field prevailing at the time of the manufacture. Directional results are plotted in Figure 4.

It is not possible to use the Fisher statistics for calculating the mean direction because the declination cannot be determined. The only geomagnetic parameter accessible is the inclination. Therefore, we use the McFadden statistics applied to inclination values. With $n=93$ specimens, we obtain:

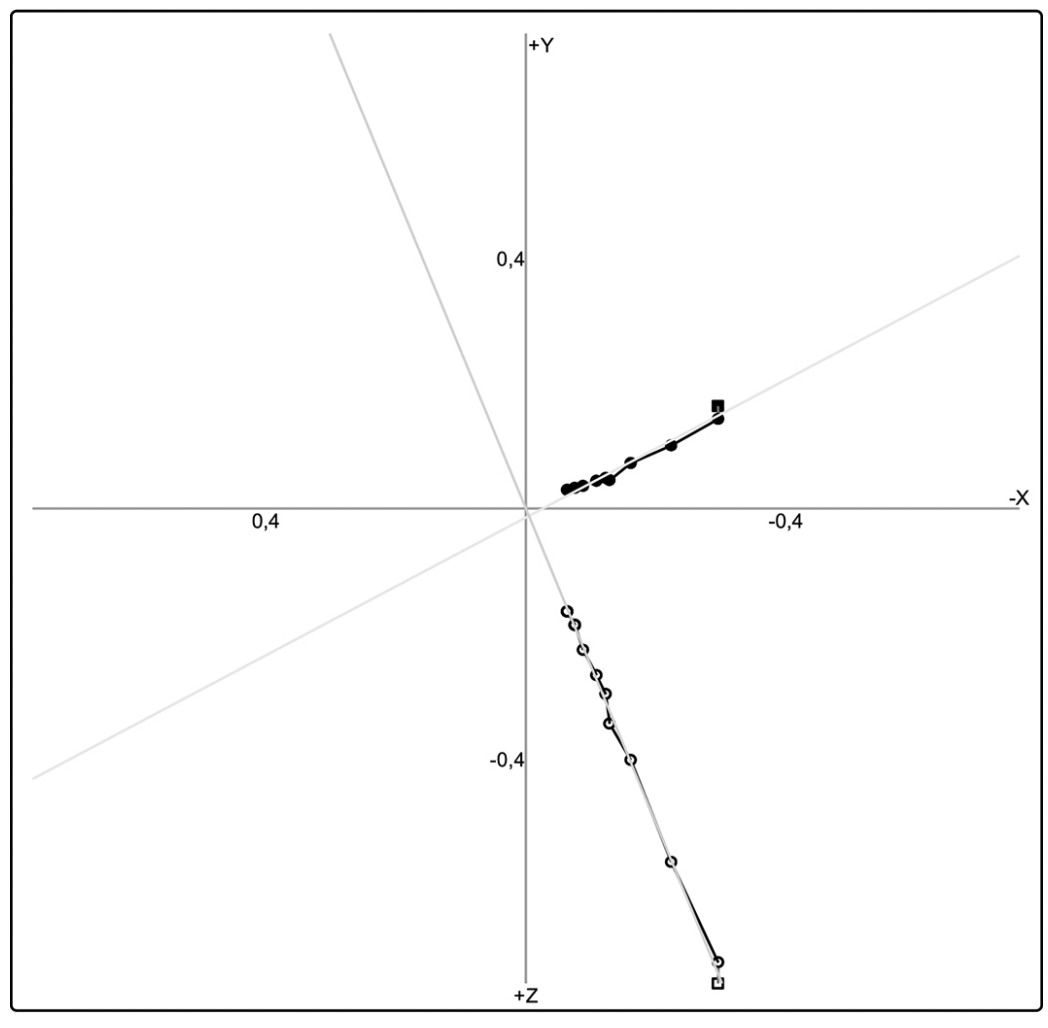

Figure 3: Demagnetization diagram (Zijderveld diagram) for specimen $1 \mathrm{~B} 1$. Thermal step points are aligned to the origin. This shows that there is only one magnetization component which corresponds to baking of the brick.

Figure 3 : Diagramme de désaimantation (diagramme de Zijderveld) du spécimen 1B1. Les étapes thermiques sont alignées à l'origine. Ceci indique quil n'y a qu'une composante d'aimantation correspondant à la cuisson de la brique. 
Figure 4: Directional results (inclination, deviation) for the 94 bricks, plotted in a stereogram. Deviation and inclination histograms, magnetization magnitude $(\mathrm{A} / \mathrm{m})$ and susceptibility (SI) histograms. Values are concentrated which is typical to a homogeneous set of bricks.

Figure 4: Résultats des directions (inclinaison, déviation) pour les 94 briques, placés sur un diagramme stéréo. Histogrammes de la déviation et de l'inclinaison, histogramme de l'intensité de l'aimantation $(A / m)$ et histogramme de la susceptibilité (SI). Les valeurs sont concentrées ce qui est typique d'un lot homogène de briques.
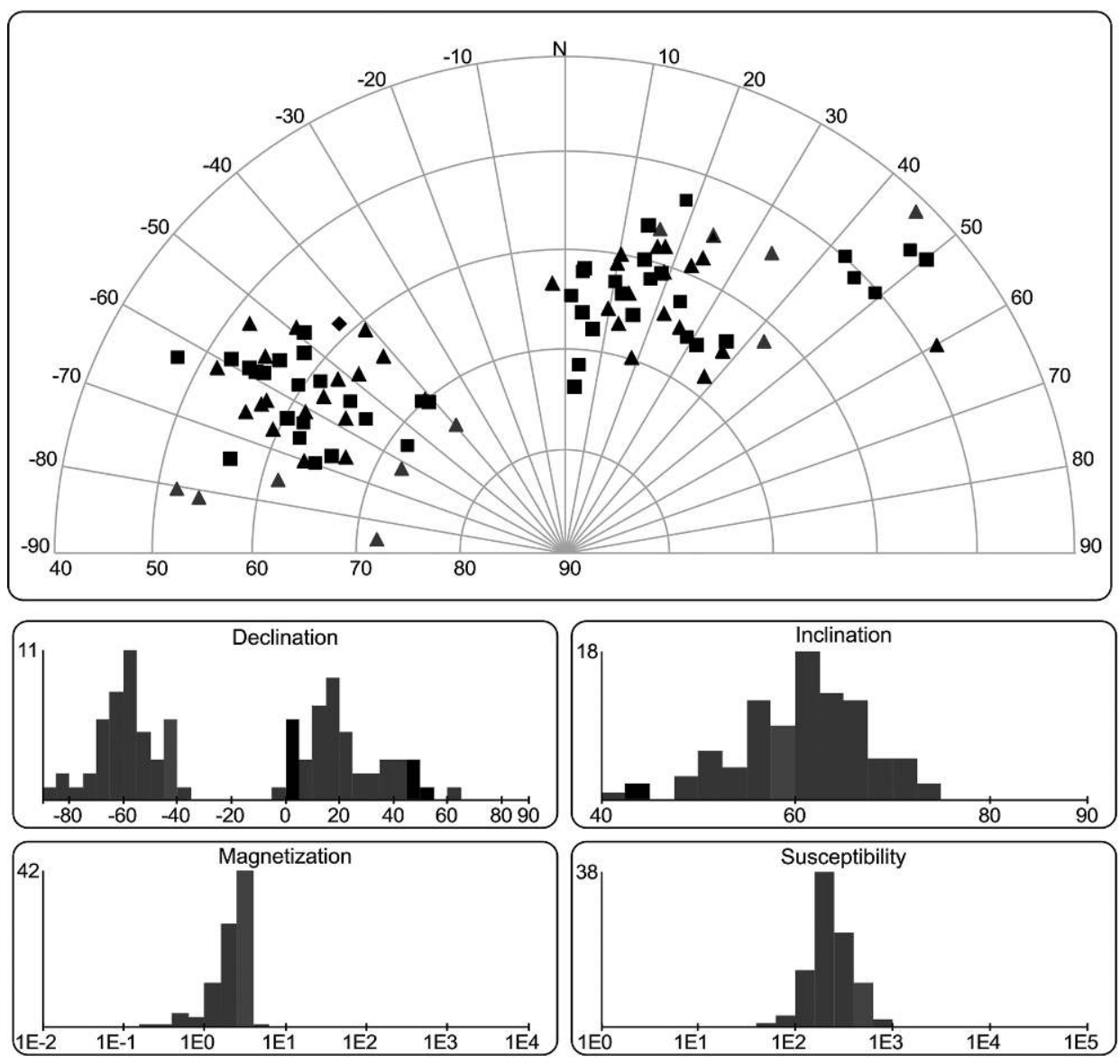

- Site location: Lat. : $45^{\circ} 50^{\prime} 48^{\prime \prime}$ North Long.: $0^{\circ} 46^{\prime}$

[-1000; -799] (26.4\%),

$[-208 ;-102] \quad(5.0 \%)$,

$[-9 ; 72] \quad(16.0 \%)$,

- Inc site $=60.7^{\circ}$;

- alpha95 (equivalent Fisher) $=1.7^{\circ}$ (directional error)

In order to convert this mean inclination in calendar date, it is necessary beforehand to transfer it at the location of Paris, the place for which the French reference curves are established. Using the VADM (virtual axial dipole moment) correction, the mean inclination at Paris becomes:

- Inc Paris $=65.2^{\circ} \pm 1.7^{\circ}$

\section{Archaeomagnetic dating results of bricks}

The determination of the inclination allows conducting archaeomagnetic dating for the manufacture of the bricks using the ChronoModel 1.5 software (Lanos et al., 2015). The inclination curve used is the reference secular variation curve at Paris for the last two millennia calculated with Rencurve software (Lanos, 2004) and using Gallet et al. (2002) directional data. As shown in Figure 5, the inclination value at Paris for the manufacture (last firing) of the bricks corresponds to six time periods at $95 \%$ confidence level (HPD region):

[434; 556]

[934; 1025]

[1527; 1584]

By combining this data with luminescence dating results and with the archaeological interpretation, one of these intervals will be preferred (see part 4).

\section{Dating of mortars by optically stimulated luminescence (SG-OSL)}

\section{Preliminary tests}

Preliminary tests consisting in a study of physical properties of the quartz grains used for OSL dating are essential to optimize the measurement protocol used for the determination of the archaeological dose. A plateau test (e.g. Murray and Olley, 2002; Wintle and Murray, 2006; Medialdea $e t$ al., 2014), a thermal transfer test (e.g. Murray \& Olley, 2002; Jain et al., 2004) and a LM-OSL test were executed 
Antibes: Bricks MR10003 (AM)

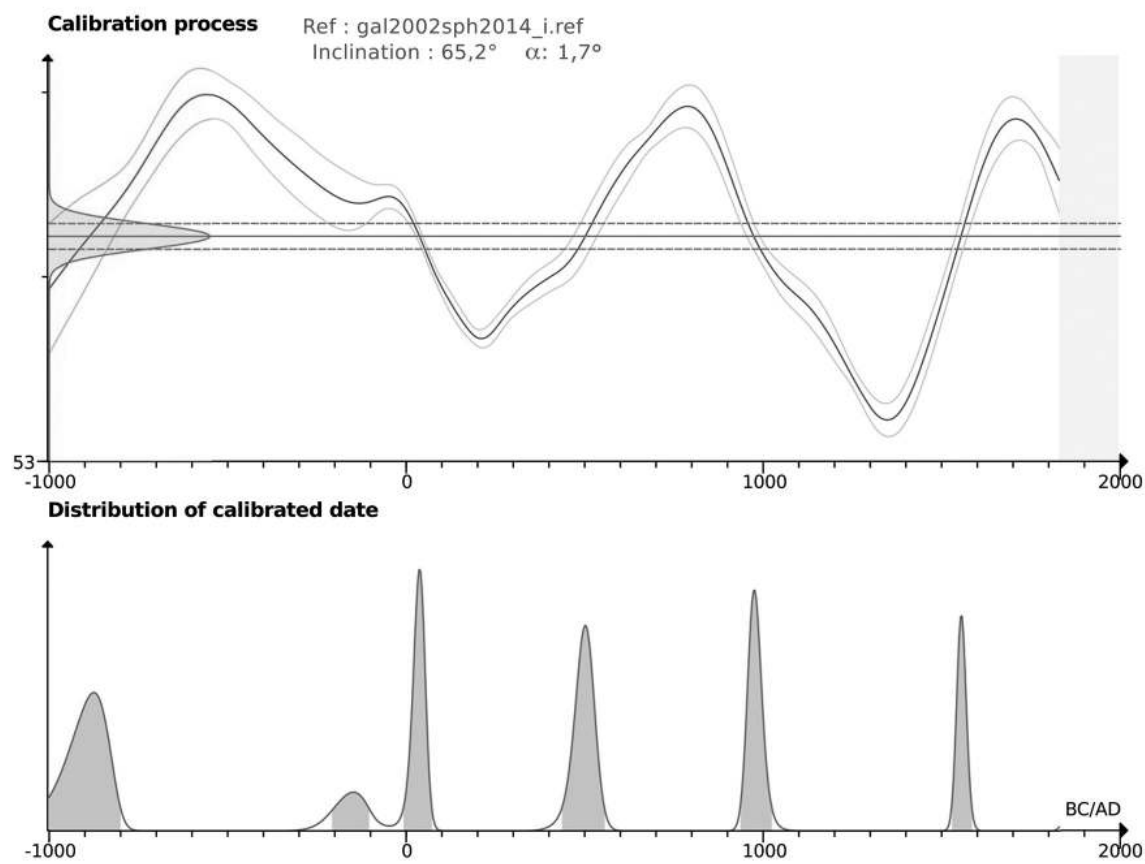

Figure 5: (See colour plate III) Dating with ChronoModel 1.5 software, based on the inclination value determined for Paris. The mean curve in blue with its confidence envelop at $95 \%$ is the reference secular variation curve at Paris for the last three millennia. See text for the predicated calendar dates obtained.

Figure 5: (Voir planche couleur III) Datation avec le logiciel ChronoModel 1.5, en utilisant la valeur de l'inclinaison déterminée à Paris. La courbe moyenne en bleu avec son enveloppe d'erreur à $95 \%$ est la courbe de variation séculaire de référence à Paris pour les trois derniers millénaires. Voir texte pour les dates calendaires présumées obtenues.

on one sample of the series, BDX 16045, showing the same luminescent properties and identical chemical and mineralogical composition with other samples. For the reason of time, these three measurements were realized by the multigrain technique.

According to the thermal transfer test realized on the artificially bleached discs, the pre-heat temperatures lower or equal to $240^{\circ} \mathrm{C}$ do not provoke a noticeable thermal transfer (Figure 6a). On the contrary, from the pre-heat temperature of $260^{\circ} \mathrm{C}$ a slight increase of the signal is observed which indicates optical and thermal drainage of electron charge from the deep traps towards the OSL traps. This tendency was noted by some other authors for young quartz samples (e.g. Murray and Clemmensen, 2001; Rhodes, 2000; Madsen et al., 2007; Medialdea et al., 2014).

As showed clearly by the LM-OSL measurement, the OSL signal of Antibes mortars is predominated by the fast component (Figure 6b), which is a precondition to date mortar by SG-OSL. The plateau test did not show any clear dependence of the measured dose on the pre-heat temperature. The smallest variations of the measured dose between the repeated measurements seem to correspond to the pre-heat temperature of $240^{\circ} \mathrm{C}$ as seen in Figure 6c, which was therefore selected for the archaeological dose determination.

\section{Archaeological dose determination}

To determine the archaeological dose, about 4,000 grains per sample were measured. Between 3.9 and 5\% of these grains emitted a detectable signal. The measurement results are summed up in the Table 2.

Distributions of individual archeological doses for the series of Antibes mortars seem relatively narrow which indicates a good degree of bleaching of these mortars. Apart from some isolated grains with higher doses, all the values are concentrated around the central dose. For this reason, the central age model (CAM; Galbraith et al., 1999) is used to calculate the average archaeological dose. The grains retained for the calculation meet following selection criteria (discussed in detail in the article Urbanová \& Guibert, in press or by other authors: Medialdea et al., 2013; Sim et al., 2014):

(a) the relative recycling ratio error $<25 \%$;

(b) the error associated with the $\mathrm{T}_{\mathrm{N}}$ signal $<25 \%$;

(c) the signal higher than 3 sigma above background.

The application of these criteria eliminates only a very small number of grains (comparison of the $3^{\text {rd }}$ and $5^{\text {th }}$ column in the Table 2). The selected grains are presented in the below histograms (Figure 7). Also, we do not observe any dependence between the relative standard errors and the associated archeological doses, which is the basic condition 
Figure 6: a) Thermal transfer test for the mortar BDX 16045 : the test consists in the measurement of the dose on artificially bleached discs at several preheat temperatures. Each point in the graph represents the mean of 6 independent measurements; b) LM-OSL test for the mortar BDX 16045: the test reflects the dependence of the measured luminescence on the stimulation power which is linearly increased during the test. The classical SG-OSL quartz dating is based on the dominant fast component detectable during the first seconds of the stimulation; c) Plateau test for the mortar BDX 16045: the test consists in the measurement of the archaeological dose at different preheat temperatures. Each point in the graph represents the mean of 6 independent measurements; d) Histogram of the measured doses from the recovery dose experiment: CAM = average dose calculated following the Central age model (Galbraith et al., 1999), OD = over-dispersion, $\mathrm{n}=$ number of measured grains.

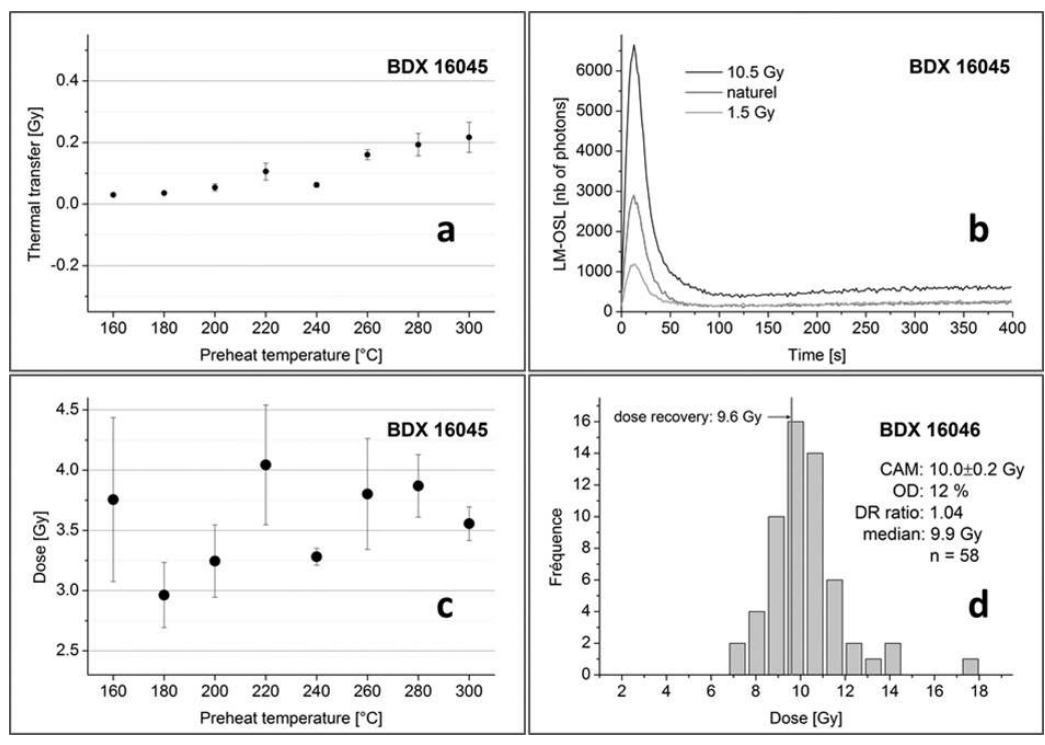

Figure 6: a) Test de transfert thermique pour le mortier BDX 16045 : Le test consiste aux mesures de la dose sur des disques artificiellement blanchis à plusieurs températures de préchauffe. Chaque point du graphique représente la moyenne des six mesures indépendantes; b) Test LM-OSL du mortier BDX 16045 : le test consiste à une mesure de la luminescence en fonction de la puissance de la stimulation qui est linéairement augmentée pendant le test. La datation par OSL classique est basée sur l'existence du composant rapide du signal détectable lors des premières secondes d'excitation; c) Test de plateau pour le mortier BDX 16045 : Le test consiste aux mesures de la dose archéologique à plusieurs températures de préchauffe effectuées sur des disques de multigrain. Chaque point du graphique représente la moyenne des six mesures indépendantes; d) Histogrammes des distributions de doses mesurées pour des grains individuels lors de tests de recovery. CAM = la dose moyenne calculée en utilisant le modèle d'âge central (Galbraith et al., 1999), OD = over-dispersion, $n=$ nombre des grains mesurés.

\begin{tabular}{|c|c|c|c|c|}
\hline Sample & Nb of grains with recovery signal & CAM recovery dose (Gy) & Over-dispersion (\%) & DR ratio \\
\hline BDX 16045 & 41 & $10.3 \pm 0.3$ & 14 & 1.07 \\
\hline BDX 16046 & 58 & $10.0 \pm 0.2$ & 8 & 1.04 \\
\hline BDX 16047 & 62 & $9.9 \pm 0.2$ & 7 & 1.03 \\
\hline BDX 16048 & 53 & $10.0 \pm 0.2$ & 5 & 1.04 \\
\hline BDX 16049 & 88 & $9.9 \pm 0.1$ & 52 \\
\hline
\end{tabular}

Table 1: Number of grains with signal after the dose recovery, recovery dose calculated using the Central age model (Galbraith et al., 1999), over-dispersion values and dose recovery ratios between the measured dose and the given recovery dose.

Tableau 1 : Nombre de grains avec le signal après la dose de recovery, dose de recovery calculée en utilisant le modèle d'age central (Galbraith et al., 1999), valeurs de l'over-dispersion et les rapports entre la dose mesurée et la dose donnée.

to justify the use of the central age model (CAM) for the calculation of the average archaeological dose. The relative standard errors vary between 5 and $20 \%$.

Since the mortar samples from Grimaldi castle in Antibes seem to be well-bleached, which is rather rare for mortar samples (compare with Goedicke, 2003 and 2011, Panzeri, 2013; Urbanová et al., 2015), the measurements of the archaeological dose by the classical multigrain (single aliquot) technique were executed. The conditions of the analyses were identical to those of the single grain measurements. Each disc contained about 50 grains.
The results of the multigrain and the single grain measurements are in a very good agreement. The exception is the sample BDX 16049 for which the deviation between these two measurements exceeds their standard errors. Nevertheless, the general agreement for the whole series of samples is satisfactory.

Since the samples were analyzed by two independent OSL techniques (single grain and multigrain), the average archaeological dose used for the age calculation was determined for each mortar sample by inverse-variance weighting associated to each of these measurements. To take 


\begin{tabular}{|c|c|c|c|c|c|c|c|}
\hline Sample & $\begin{array}{c}\text { Nb of analyzed } \\
\text { grains }\end{array}$ & $\begin{array}{c}\text { Nb of grains } \\
\text { with OSL signal }\end{array}$ & $\begin{array}{c}\text { \% of grains with } \\
\text { OSL signal }\end{array}$ & $\begin{array}{c}\text { Nb of selected } \\
\text { grains }\end{array}$ & $\begin{array}{c}\text { \% of selected } \\
\text { grains }\end{array}$ & $\begin{array}{c}\text { Archeological } \\
\text { dose }(\text { Gy })\end{array}$ & $\begin{array}{c}\text { Over-dispersion } \\
(\%)\end{array}$ \\
\hline BDX 16045 & 4085 & 200 & 5.0 & 196 & 4.1 & $3.85 \pm 0.10$ & 31 \\
\hline BDX 16046 & 3800 & 193 & 5.0 & 180 & 4.7 & $3.56 \pm 0.09$ & 31 \\
\hline BDX 16047 & 3800 & 179 & 4.8 & 175 & 4.6 & $4.60 \pm 0.16$ & 43 \\
\hline BDX 16048 & 3990 & 205 & 4.9 & 189 & 4.7 & $3.66 \pm 0.08$ & 27 \\
\hline BDX 16049 & 4085 & 163 & 3.9 & 152 & 3.7 & $3.89 \pm 0.13$ & 36 \\
\hline
\end{tabular}

Table 2: Number of analyzed grains, number of grains emitting an OSL signal and number of grains selected for the calculation of the archaeological dose, values of average archeological doses with the standard deviation for each sample calculated according to Central age model (CAM) and over-dispersion values describing the spread between individual archaeological doses within the same sample caused by another factor than by a statistical uncertainty.

Tableau 2 : Nombre de grains de quartz étudiés, du nombre de grains de quartz ayant montré une sensibilité suffisante, du nombre de grains retenus pour la détermination de la dose archéologique, repart de la dose archéologique mesurée selon le modèle d’àge central (CAM, Galbraith et al., 1999) avec son écart-type statistique, et le terme d'over-dispersion qui rend compte de l'accroissement de dispersion de la distribution des doses lié à d'autres causes que la seule incertitude statistique des mesures des doses archéologiques individuelles.

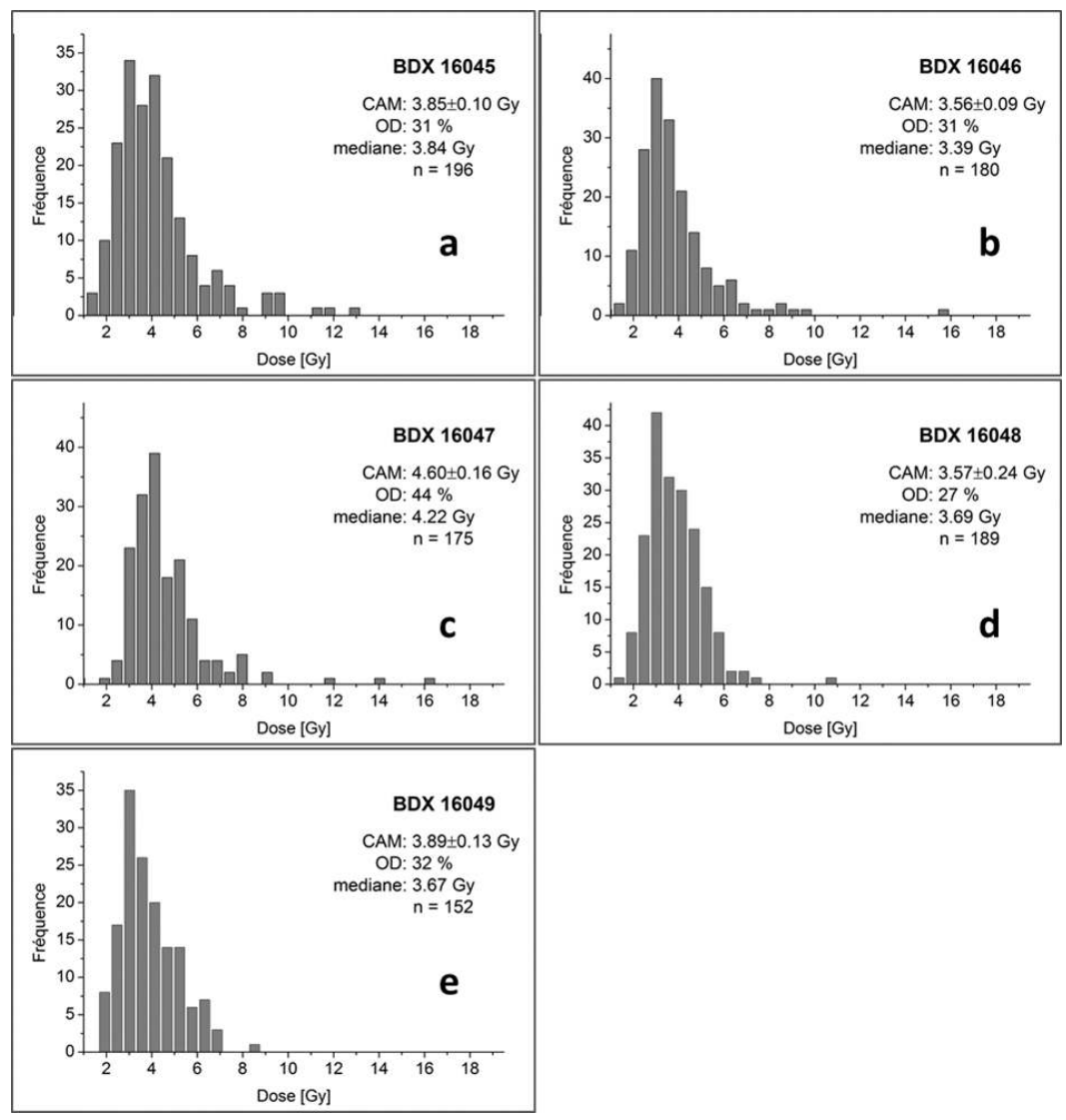

Figure 7: Histograms (a, b, c, d, e) show the distributions of individual archaeological doses from the single grain measurements. The dispersion of the data is caused probably by the combination of intrinsic variability (occurring naturally between the single grains) and microdosimetric effects (see paragraph 3) rather than by insufficient bleaching (that would show as a long tail at the right side of each distribution, which is not the case). Average archaeological doses (CAM) and over-dispersion values (OD) for the number of grains $n$ calculated using the central age model (CAM, Galbraith et al., 1999)

Figure 7 : Histogrammes des distributions de doses archéologiques pour des grains individuels. La dispersion des données résulte probablement de la combinaison de la variabilité intrinsèque (naturellement existant entre des grains) et de la variabilité microdosimétrique (voir paragraphe 3) plutôt que du blanchiment insuffisant (qui se projetterait dans la distribution des doses comme un queue à droite). Les doses archéologiques moyennes (CAM) et les valeurs de l'over-dispersion (OD) pour le nombre de grains n étaient calculées en utilisant le modèle d'àge central (CAM, Galbraith et al., 1999). into account possible anomalous deviations (greater than expected by statistical uncertainties) between the measurements, the experimental deviation between the single grain and the multigrain measurement was integrated in the establishment of the measurement uncertainty calculated according to the following equation:

$$
s=\sqrt{w_{1}^{2}\left(\sigma_{1}^{2}+\left(D_{1}-D_{m}\right)^{2}\right)+w_{2}^{2}\left(\sigma_{2}^{2}+\left(D_{2}-D_{m}\right)^{2}\right)}
$$

where $\mathrm{D}_{1}$ and $\mathrm{D}_{2}$ are average archaeological doses for the single grain and the multigrain measurement, respectively, $\sigma_{1}$ and $\sigma_{2}$ the associated standard deviations, $\mathrm{w}_{1}$ and $\mathrm{w}_{2}$ the corresponding calculated weights and $\mathrm{D}_{\mathrm{m}}$ the average 
archaeological dose calculated by inverse-variance weighting. For the samples BDX 16048 and BDX 16049, the measurement uncertainty is higher because of the larger difference between the single grain and the multigrain measurement. For the final age calculation, the average archaeological doses in the $6^{\text {th }}$ column of Table 3 were taken into account.

\section{Microdosimetry caracteristics}

The over-dispersion values associated to the archaeological (natural) doses are higher (from 27 to 44\%, Table 1) than the over-dispersion values of dose recovery measurements (from 5 to $14 \%$, Table 2). This difference indicates the presence of some external dispersive factor that provokes this supplementary variability between the archaeological (natural) doses. In Urbanová et al. (2015) dealing with OSL dating of mortars, two principal possible sources of dispersion of archaeological doses were discussed: heterogeneous bleaching and differences in dose rate at the grain scale. However, as seen in the paragraph above, Antibes mortars are well-bleached, which was confirmed by the agreement of the multigrain and the single grain measurements. Thick sections of the studied samples were thus analyzed by SEMEDX cartography and beta-imaging system in order to evaluate qualitatively microdosimetric properties of Antibes mortars. All the samples had very similar character.

The images from beta autoradiography show quite an important number of beta emitters that are relatively homogeneously spread in mortar matrix (Figure 8a). For a better visual interpretation, these images are presented together with macroscopic photos of the studied thick sections. The brightest tiny points correspond probably to apatite minerals identified sporadically by SEM-EDX analyses.

In general terms, the mortars seem to be homogeneous, fine-grained, containing rather angular grains smaller than
$1 \mathrm{~mm}$ in diameter, quartz being the most abundant of all minerals. Petrographic observations (Figure 8c) confirm a significant amount of potassium feldspars and micas in the thin sections of Antibes mortars. All these minerals seem to be uniformly distributed.

According to the SEM-EDX mapping the mortars contain a large quantity of $\mathrm{K}_{2} \mathrm{O}$ rich minerals (Figure 8d, 8f) which is in agreement with the petrographic observations. Point SEM-EDX analyses show that $\mathrm{K}_{2} \mathrm{O}$ content can vary from 1 to $3 \%$ in different areas of mortar matrix (Figure 8e), which causes microdosimetric variations of the dose rate.

\section{Dose rate}

The concentrations of radioelements in the studied mortar samples determined by low-background gamma spectrometry (Guibert and Schvoerer, 1991, Guibert et al., 2009) are showed in the Table 4. No particular relationship between the position of the samples in the structure and the content of radioelements was observed.

${ }^{210} \mathrm{~Pb}$ and ${ }^{226} \mathrm{Ra}$ are in disequilibrium. In general, the activity of ${ }^{226} \mathrm{Ra}$ is higher than the activity of ${ }^{210} \mathrm{~Pb}$ which is interpreted as a continuous loss of radon since the last 30 years in the corresponding part of the building. If the castle foundations have never been buried, a permanent loss of radon since the construction of the structure can be supposed. Therefore, the ages are estimated taking into account this hypothesis according to which ${ }^{210} \mathrm{~Pb}$ indicates the average activity of ${ }^{222} \mathrm{Rn}$ and its daughters since the erection of the masonry.

${ }^{238} \mathrm{U}$ and ${ }^{226} \mathrm{Ra}$ are also slightly in disequilibrium. Whereas the $\mathrm{U} / \mathrm{Th}$ ratios indicate low variability, variability of $\mathrm{Ra}$ is according to the $\mathrm{Ra} / \mathrm{Th}$ ratios much more important (Table 4). The number of samples is insufficient to interpret with absolute certainty the cause of the mentioned disequilibrium (contrary to

\begin{tabular}{|c|c|c|c|c|c|}
\hline Sample & $\begin{array}{c}\text { Archaeological dose } \\
\text { monograin (Gy) }\end{array}$ & Nb of multigrain discs & $\begin{array}{c}\text { Archaeological dose } \\
\text { multi-grain (Gy) }\end{array}$ & $\begin{array}{c}\text { Euclidian distance } \\
\text { (monograin-multi-grain) }\end{array}$ & $\begin{array}{c}\text { Average archaeological } \\
\text { dose (Gy) }\end{array}$ \\
\hline BDX 16045 & $3.85 \pm 0.10$ & 21 & $3.78 \pm 0.21$ & -0.30 & $3.84 \pm 0.09$ \\
\hline BDX 16046 & $3.56 \pm 0.09$ & 24 & $3.69 \pm 0.20$ & 0.59 & $3.58 \pm 0.09$ \\
\hline BDX 16047 & $4.60 \pm 0.16$ & 22 & $4.54 \pm 0.15$ & -0.27 & $4.57 \pm 0.11$ \\
\hline BDX 16048 & $3.66 \pm 0.08$ & 23 & $4.01 \pm 0.16$ & 1.96 & $3.73 \pm 0.11$ \\
\hline BDX 16049 & $3.89 \pm 0.13$ & 24 & $3.30 \pm 0.10$ & -3.60 & $3.52 \pm 0.21$ \\
\hline
\end{tabular}

Table 3: Values of the average archaeological dose from the single grain measurements, number of analyzed discs, values of the average archeological doses with the standard deviation for each sample from the multigrain measurements, the Euclidian distance between the multigrain and the single grain measurements and the final value of the average archaeological dose calculated by inverse-variance weighting with the associated standard deviation.

Tableau 3 : Rappel de la dose archéologique moyenne obtenue par OSL monograin, nombre de disques multi-grains utilisés selon la méthode conventionnelle, dose archéologique et écart-type statistique correspondants, distance euclidienne réduite entre les mesures monograin et multigrains, et valeur moyenne finale de la dose archéologique avec écart-type statistique associé. 


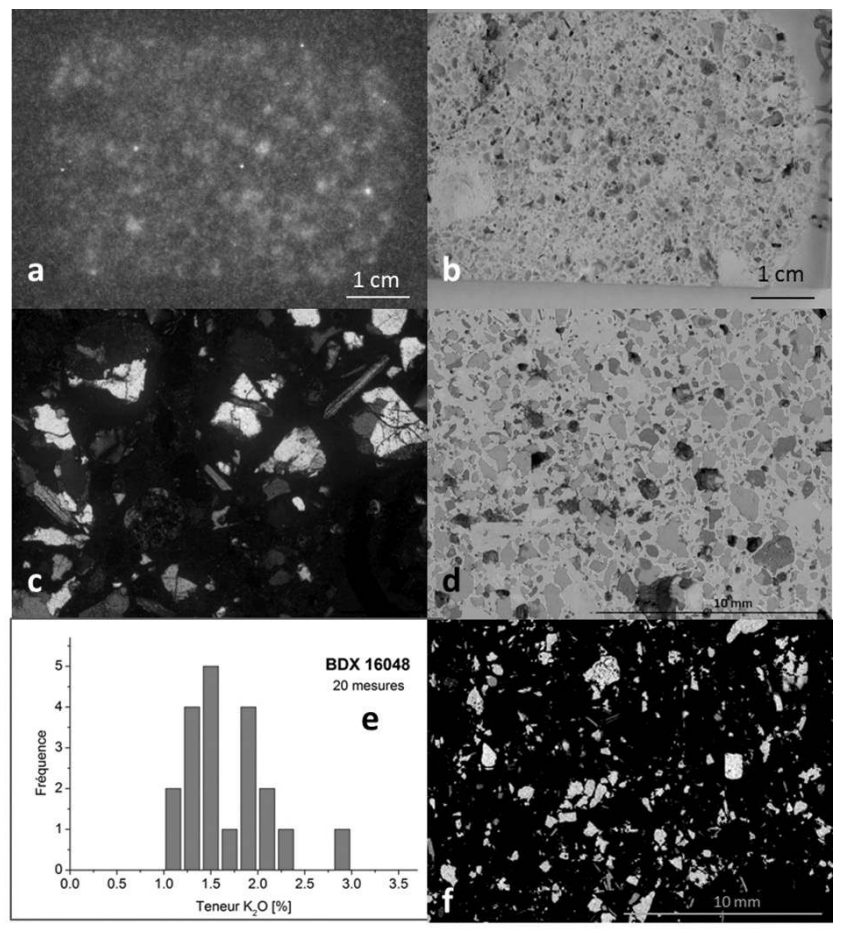

Figure 8: (See colour plate III) a) Image from beta-autoradiography of the mortar sample BDX 16048. The brightest spots correspond to the most intense beta emitters; b) Macroscopic picture of the mortar sample BDX 16048; c) Observation (x50) of the thin section of the sample BDX 16048 in cross-polarized light; d) Interpretation of the SEM-EDX carthography performed on the thick section of the sample BDX 16048. Each colour corresponds to the most represented element: in red - silicium (quartz minerals), in blue - potassium (potassium minerals), en green - calcium (carbonated matrix); e) Histogram representing the distribution of potassium in the mortar sample BDX 16048 based on the spot analyses including a radius of $2 \mathrm{~mm}$ around the quartz grains used for SG-OSL measurements; f) SEM-EDX carthography of potassium rich minerals in the sample BDX 16048. The grey level corresponds to the number of $\mathrm{X}$ rays emitted by potassium detected by the instrument. Magnification: 60, pixel size: $0.03 \mathrm{~mm}$.

Figure 8: (Voir planche couleur III) a) Images de l'autoradiographie beta de l'échantillon BDX 16048. Les points plus clairs correspondent aux endroits plus radioactifs (émissions beta); b) Photos macroscopiques du mortier correspondant; c) Observation (x50) de la lame mince de l'échantillon BDX 16045 en lumière polarisée analysée; d) Interprétation d'une cartographie élémentaire par $E D X-M E B$, effectuée sur la lame épaisse de l'échantillon BDX 16048. Chaque couleur correspond à un élément majeur d'un endroit analysé: en rouge - silicium (minéraux de quartz), en bleu - potassium (minéraux potassiques), en vert - calcium (liant calcaire); e) Histogramme de distribution du potassium dans le mortier BDX 16048 basés sur les mesures ponctuelles du rayon de 2 millimètres réalisées autour des grains de quartz utilisés pour la datation par SG-OSL; f) Images de répartition du potassium, obtenues par cartographie EDX-MEB pour l'échantillon BDX 16048. Le niveau de gris correspond au nombre de rayons Xémis par potassium atteignant le détecteur en fonction d'un endroit analysé. Grandissement: 60. Taille du pixel: $0.03 \mathrm{~mm}$.

\begin{tabular}{|c|c|c|c|c|c|c|}
\hline Sample & Water content [\%] & $\mathrm{K}[\%]$ & $\mathrm{U}\left({ }^{(238} \mathrm{U}\right)[\mathrm{ppm}]$ & $\mathrm{U}(226 \mathrm{Ra})[\mathrm{ppm}]$ & $\mathrm{U}\left({ }^{210} \mathrm{~Pb}\right)[\mathrm{ppm}]$ & $\mathrm{Th}[\mathrm{ppm}]$ \\
\hline BDX 16045 & $5.0 \pm 1.5$ & $1.43 \pm 0.03$ & $1.68 \pm 0.12$ & $1.77 \pm 0.04$ & $1.66 \pm 0.21$ & $2.31 \pm 0.07$ \\
\hline BDX 16046 & $6.0 \pm 1.7$ & $1.44 \pm 0.03$ & $1.46 \pm 0.11$ & $1.81 \pm 0.04$ & $1.43 \pm 0.19$ & $2.11 \pm 0.06$ \\
\hline BDX 16047 & $13.0 \pm 3.8$ & $1.88 \pm 0.03$ & $1.60 \pm 0.12$ & $1.86 \pm 0.04$ & $1.27 \pm 0.21$ & $2.89 \pm 0.07$ \\
\hline BDX 16048 & $10.0 \pm 2.9$ & $1.94 \pm 0.03$ & $2.02 \pm 0.10$ & $2.36 \pm 0.04$ & $1.66 \pm 0.17$ & $2.67 \pm 0.06$ \\
\hline BDX 16049 & $13 \pm 3.8$ & $1.74 \pm 0.04$ & $1.99 \pm 0.13$ & $1.42 \pm 0.04$ & $1.43 \pm 0.24$ & $2.83 \pm 0.08$ \\
\hline
\end{tabular}

Table 4: Water content taken into account for age determination and $\mathrm{K}$, $\mathrm{U}$ and Th content detected by low-background gamma spectrometry.

Tableau 4: Mesure de l'humidité à saturation (\% de masse d'eau à saturation par rapport à la masse de matériau sec), teneurs en $K$, $U$ et $T h$ déterminées par spectrométrie gamma à bas bruit de fond.

some other studies such as Guibert et al., 2009). Nevertheless, since the ${ }^{226} \mathrm{Ra}$ content varies more than the ${ }^{238} \mathrm{U}$ content, a hypothesis of the $\mathrm{Ra}$ alteration rather than of the $\mathrm{U}$ alteration can be raised (as observed for example on the series of bricks from the church St Martin in Angers; Blain et al., 2011).

We assumed that the whole series of Antibes mortars was affected by the same alteration phenomenon. The influence of different possible alteration phenomena on the dose rate values was tested by applying two disequilibrium models (each of them for two different kinetics laws):

1. The disequilibrium is due to a mobility of uranium isotopes

- We suppose that the disequilibrium is inherited from raw material at the moment of the mortar preparation. In this case, the disequilibrium is considered constant (the age of mortar is much younger than the half-life of 75200 years of ${ }^{230} \mathrm{Th}$ ) and the measured activities of ${ }^{238} \mathrm{U},{ }^{226} \mathrm{Ra}$ 
and ${ }^{210} \mathrm{~Pb}$ represent the average activities since the fabrication of mortar.

- We suppose that the disequilibrium is recent. Here the alteration process took place quite recently with regard to the age of the samples. The $U$ content would be thus represented by the ${ }^{226} \mathrm{Ra}$ activity.

2. The disequilibrium is due to a mobility of radium

- We suppose that the disequilibrium is inherited from raw material at the moment of the mortar preparation. The radioactive period for ${ }^{226} \mathrm{Ra}$ ( 1600 years) is similar to the age of the samples. It cannot be assumed that the radium concentration remained constant during the existence of the dated structure. The progressive return of ${ }^{226} \mathrm{Ra}$ to equilibrium since the fabrication of mortar was thus assumed. In this case, the significant indicator of radioactivity during the existence of the masonry is the average content of $\mathrm{U}\left({ }^{226} \mathrm{Ra}\right)$. The loss of ${ }^{222} \mathrm{Rn}$ was considered constant through time and the mean activity of ${ }^{222} \mathrm{Rn}$ and its daughters was recalculated with this average $\mathrm{Ra}$ activity respecting the ratio ${ }^{210} \mathrm{~Pb} / 226 \mathrm{Ra}$ measured.

- The Ra disequilibrium is recent. Here the alteration which took place quite recently with regard to the age of the samples has modified all the $U$ chain beginning with ${ }^{226} \mathrm{Ra}$. The Ra content would be thus deduced from the ${ }^{238} \mathrm{U}$ activity. Following the same assumption as for the preceding case, the average activity of radon and the daughters was calculated respecting the ratio ${ }^{210} \mathrm{~Pb} / 226 \mathrm{Ra}$ measured.

\begin{tabular}{|c|c|c|c|c|c|c|}
\hline \multirow{2}{*}{ Sample } & \multicolumn{5}{|c|}{ Annual dose (mGy/a) } & \multirow{2}{*}{ OSL age (years) } \\
\hline & $\alpha$ & $\mathrm{B}$ & Intrinsic & Environmental & Total & \\
\hline \multicolumn{7}{|c|}{ BDX 16045} \\
\hline $\mathrm{Ra}$ ancient & $0.021 \pm 0.009$ & $1.249 \pm 0.044$ & $1.270 \pm 0.045$ & \multirow{4}{*}{$0.560 \pm 0.036$} & $1.830 \pm 0.074$ & $2100 \pm 100(60)$ \\
\hline Ra recent & $0.020 \pm 0.008$ & $1.240 \pm 0.043$ & $1.260 \pm 0.045$ & & $1.820 \pm 0.073$ & $2110 \pm 100(60)$ \\
\hline U ancient & $0.021 \pm 0.009$ & $1.246 \pm 0.043$ & $1.267 \pm 0.045$ & & $1.827 \pm 0.074$ & $2100 \pm 100(60)$ \\
\hline U recent & $0.021 \pm 0.009$ & $1.250 \pm 0.043$ & $1.271 \pm 0.045$ & & $1.831 \pm 0.074$ & $2100 \pm 100(60)$ \\
\hline \multicolumn{7}{|c|}{ BDX 16046} \\
\hline $\mathrm{Ra}$ ancient & $0.019 \pm 0.008$ & $1.213 \pm 0.047$ & $1.233 \pm 0.048$ & \multirow{4}{*}{$0.500 \pm 0.031$} & $1.733 \pm 0.076$ & $2070 \pm 100(60)$ \\
\hline Ra recent & $0.017 \pm 0.007$ & $1.184 \pm 0.046$ & $1.201 \pm 0.047$ & & $1.701 \pm 0.074$ & $2100 \pm 100(60)$ \\
\hline U ancient & $0.019 \pm 0.008$ & $1.204 \pm 0.046$ & $1.223 \pm 0.048$ & & $1.723 \pm 0.075$ & $2080 \pm 100(60)$ \\
\hline U recent & $0.019 \pm 0.008$ & $1.220 \pm 0.047$ & $1.239 \pm 0.048$ & & $1.739 \pm 0.076$ & $2060 \pm 100(60)$ \\
\hline \multicolumn{7}{|c|}{ BDX 16047} \\
\hline $\mathrm{Ra}$ ancient & $0.019 \pm 0.008$ & $1.431 \pm 0.105$ & $1.450 \pm 0.106$ & \multirow{4}{*}{$0.840 \pm 0.056$} & $2.290 \pm 0.173$ & $1990 \pm 140(60)$ \\
\hline Ra recent & $0.018 \pm 0.007$ & $1.413 \pm 0.103$ & $1.431 \pm 0.105$ & & $2.271 \pm 0.171$ & $2010 \pm 140(60)$ \\
\hline U ancient & $0.019 \pm 0.008$ & $1.426 \pm 0.104$ & $1.445 \pm 0.106$ & & $2.285 \pm 0.172$ & $2000 \pm 140(60)$ \\
\hline U recent & $0.020 \pm 0.008$ & $1.436 \pm 0.105$ & $1.456 \pm 0.107$ & & $2.296 \pm 0.173$ & $1990 \pm 140(60)$ \\
\hline \multicolumn{7}{|c|}{ BDX 16048} \\
\hline $\mathrm{Ra}$ ancient & $0.023 \pm 0.012$ & $1.567 \pm 0.085$ & $1.590 \pm 0.088$ & \multirow{4}{*}{$0.490 \pm 0.031$} & $2.080 \pm 0.132$ & $1790 \pm 110(60)$ \\
\hline Ra recent & $0.021 \pm 0.009$ & $1.542 \pm 0.083$ & $1.563 \pm 0.085$ & & $2.053 \pm 0.129$ & $1820 \pm 110(60)$ \\
\hline U ancient & $0.023 \pm 0.009$ & $1.559 \pm 0.084$ & $1.582 \pm 0.086$ & & $2.072 \pm 0.130$ & $1800 \pm 110(60)$ \\
\hline U recent & $0.023 \pm 0.010$ & $1.574 \pm 0.085$ & $1.597 \pm 0.087$ & & $2.087 \pm 0.131$ & $1790 \pm 110(60)$ \\
\hline \multicolumn{7}{|c|}{ BDX 16049} \\
\hline Ra ancient & $0.019 \pm 0.008$ & $1.352 \pm 0.088$ & $1.371 \pm 0.089$ & \multirow{4}{*}{$0.530 \pm 0.037$} & $1.901 \pm 0.137$ & $1850 \pm 160(120)$ \\
\hline Ra recent & $0.022 \pm 0.010$ & $1.409 \pm 0.091$ & $1.433 \pm 0.094$ & & $1.963 \pm 0.142$ & $1790 \pm 150(110)$ \\
\hline U ancient & $0.020 \pm 0.008$ & $1.371 \pm 0.089$ & $1.391 \pm 0.091$ & & $1.921 \pm 0.139$ & $1860 \pm 160(110)$ \\
\hline U recent & $0.019 \pm 0.008$ & $1.347 \pm 0.087$ & $1.366 \pm 0.089$ & & $1.896 \pm 0.136$ & $1860 \pm 160(120)$ \\
\hline
\end{tabular}

Table 5: For each contribution, the annual dose is calculated following four scenarios of disequilibrium described in the text (uncertainty $=1$ std deviation). OSL age and corresponding global standard deviation are expressed in years (with regard to the year of analyses being 2014) and presented rounded to the closest ten. Statistical component of the standard deviation is indicated in brackets.

Tableau 5: Dose annuelle absorbée en moyenne par les grains de quartz des mortiers étudiés dans ce travail a été calculée pour chaque composante les valeurs de dose annuelle selon les 4 scénarios de déséquilibre au niveau de l'uranium et du radium explicités dans le texte. L'âge OSL exprimé en années (par rapport à la date de l'analyse, 2014) est présenté arrondi à la dizaine d'années la plus proche, associé à son incertitude globale (estimée à un écart-type), elle aussi exprimée en années. Entre parenthèses, nous avons indiqué la composante statistique de l'écart-type. 
The annual dose was determined according to these four scenarios (Table 5) using the content/annual dose conversion factors published by Guérin et al. (2011). It was considered that only the $\alpha$ and $\beta$ internal components were affected by this disequilibrium, whereas the external $\gamma$ and cosmic doses measured by dosimetry were assumed constant. As a result, the annual dose does not seem to vary significantly with regard to the origin of the disequilibrium and its duration. Negligible variability is related mainly to the fact that the contribution of uranium to the annual dose rate takes a minor part. Also, a combination of relative values of $U\left({ }^{226} \mathrm{Ra}\right), \mathrm{U}\left({ }^{238} \mathrm{U}\right)$ and $\mathrm{U}\left({ }^{(10} \mathrm{Pb}\right)$ lead to the values that are very similar.

The Table 5 sums up all the contributions to the annual dose rate. The uncertainty associated to each value of the annual dose rate represents a standard deviation resulting from the quadratic combination of statistical uncertainties (counting statistics of gamma spectrometry measurements, the OSL measurement error, the dosimetry measurement error) and systematic errors. Among the latter ones, the uncertainty on the measurement of humidity, which is proportional to porosity of the material, represents an important part to be taken into account.

The major part of the uncertainty on the $\alpha$ component originates from the estimation of $\alpha$ efficacy factor ( $k$-value). Finally, for the contribution of environment, a supplementary uncertainty representing $5 \%$ of the measured value was added with regard to potential non-identified variations affecting the masonry in time. This uncertainty is included in the determination of a systematic error. The environmental dose rate is constant and rather low for the mortar samples taken from the parts further from the brick courses, whereas the mortar sample BDX 16047 originating from the zone located in the close neighborhood with bricks being naturally more radioactive than stones shows much higher value.

\section{SG-OSL dating results of mortars}

The final OSL ages of Antibes mortars are presented in the Table 6. The uncertainties associated to the SG-OSL ages correspond to the estimation of the total standard deviation resulting from a quadratic combination of statistical and systematical uncertainties. The statistical part of the uncertainty is indicated in brackets. The maximum differences between the ages of each sample calculated following the four scenarios defined for the disequilibrium of uranium series are not very important: 10 years for BDX 16045, 20 for BDX 16047, 30 for BDX 16048, 40 for BDX 16046 and 70 for BDX 16049 (Table 5). The ages evaluated according to the scenario of the ancient disequilibrium of uranium were taken into account to determine the final OSL age of the masonry that was calculated by inverse-variance weighting of five individual ages.

The SG-OSL results obtained for mortar samples from Grimaldi castle foundations served as input data for testing the accuracy of a Bayesian central-dose model for singlegrain OSL published by Guérin et al. (2015). At the present time we have slight but not significant differences in the single grain data between Guérin's 2015 paper and the present one. The dose rates in Guérin's article were calculated without taking into account the disequilibrium in uranium series. In addition, the grains with relative uncertainties higher than 30\% were not included in the determination of the central dose (CAM), so the number of grains presented in Guérin et al. (2015) is slightly lower than the number of grains presented in this paper. The small differences in the

\begin{tabular}{|c|c|c|c|c|c|}
\hline Sample & OSL age & Global uncertainty & Statistical uncertainty & Weighting & Reduced euclidian d \\
\hline Bdx 16045 & 2102 & 100 & 58 & 0.240 & 2.05 \\
\hline Bdx 16046 & 2078 & 104 & 61 & 0.217 & 0.240 \\
\hline Bdx 16047 & 2000 & 137 & 58 & 0.240 & 0.29 \\
\hline Bdx 16048 & 1800 & 110 & 114 & 0.062 & -3.16 \\
\hline Bdx 16049 & 1833 & 156 & 62 & & \\
\hline Average weighted age & 1983 & 115 & & \\
\hline Average weighted date & 31 A.D. & & & \\
\hline
\end{tabular}

Table 6: Average OSL age and date of the construction of Grimaldi castle foundations in Antibes. nformation presented in the table includes: global and statistical uncertainties associated to the OSL ages, a relative weight of each OSL age for the calculation of the average OSL age and reduced Euclidian distances between individual OSL ages and the average OSL age.

Tableau 6 : Âge et date OSL moyenne des échantillons de mortier prélevés sur les fondations romaines du Château Grimaldi à Antibes. Nous avons précisé l'incertitude globale associée aux âges, ainsi que leur incertitude statistique, la pondération relative à chaque résultat pour le calcul de la moyenne et les distances euclidiennes réduites entre les âges individuels et la valeur moyenne. 
data evaluation resulting from the methodological progress do not provoke significant differences between the ages presented in these two papers.

The mortars from Grimaldi castle in Antibes contain quartz aggregate that was well bleached at the moment of the construction of the building and could have been therefore easily dated. The good degree of bleaching was demonstrated by a perfect agreement of the single grain and the multigrain measurements. The dating results for five mortar samples taken in different parts of the wall MR 10003 are coherent.

\section{Chronological SyNTHesis AND CONCLUSiON}

The chronology determining the construction of the Grimaldi castle foundations results from four independent dating approaches:

- archaeological analysis of the ceramic shard found in the upper part of the circular pit located under the dated masonry reveals the terminus post quem 60-100 A.D. for the construction of the masonry.

- archaeomagnetic dating of the series of 94 bricks (Figure 5);

- single grain OSL dating of 5 mortars;

- multigrain OSL dating of the same 5 mortars.

In order to determine a chronological interval of the construction of the masonry by taking into account all the data and their relationships, the results of archaeomagnetic

Figure 9: (See colour plate IV) Presentation of the ChronoModel procedure (Lanos et al., 2015) at 95\% confidence level; a: a posteriori interval of the construction Event of the castle foundations; $b$ : archaeomagnetic dating results for the studied brick set: calibrated distribution (line) and a posteriori distributions (light grey color); c-g: SG-OSL dating results for each mortar sample (a priori and $a$ posteriori probability distributions); h: final chronological interval for the terminus post quem of the construction of the castle foundations; i: archaeological hypothesis (probability distribution) for the terminus post quem of the construction of the castle foundations. Figure 9: (Voir planche couleur IV) Présentation de la procedure ChronoModel (Lanos et al., 2015) à $95 \%$ de probabilité. a : distribution de probabilité a posteriori du fait "construction " des soubassements du château; $b$ : résultats de datation par l'archéomagnétisme pour la série des briques étudiées : distribution calibrée (ligne) et distribution de probabilité a posteriori (gris clair); c-g : résultats de datation par SG-OSL pour chaque échantillon du mortier (distributions de probabilité a priori et a posteriori ; $h$ : intervalle chronologique final pour le terminus post quem de la construction des soubassements du château; $i$ : hypothèse archéologique (distribution de probabilité) pour le terminus post quem de la construction des soubassements $d u$ château. dating and OSL dating were associated to the same event: the construction of the wall. The bricks are therefore supposed to have been used directly after their manufacture. This event was considered as subsequent to the terminus post quem revealed by typo-chronological dating of the ceramic shard.

A statistical combination of all the data was performed by means of the ChronoModel procedure (Lanos et al., 2015) at 95\% confidence level. The Figure 9 shows the process of data evaluation. The Figures $9 \mathrm{a}$ and $9 \mathrm{~h}$ show final chronological intervals of the construction of the Grimaldi castle foundations and terminus post quem, respectively. The Figures $9 \mathrm{~b}-\mathrm{g}$ and $9 \mathrm{i}$ are the results of the overlapping of:

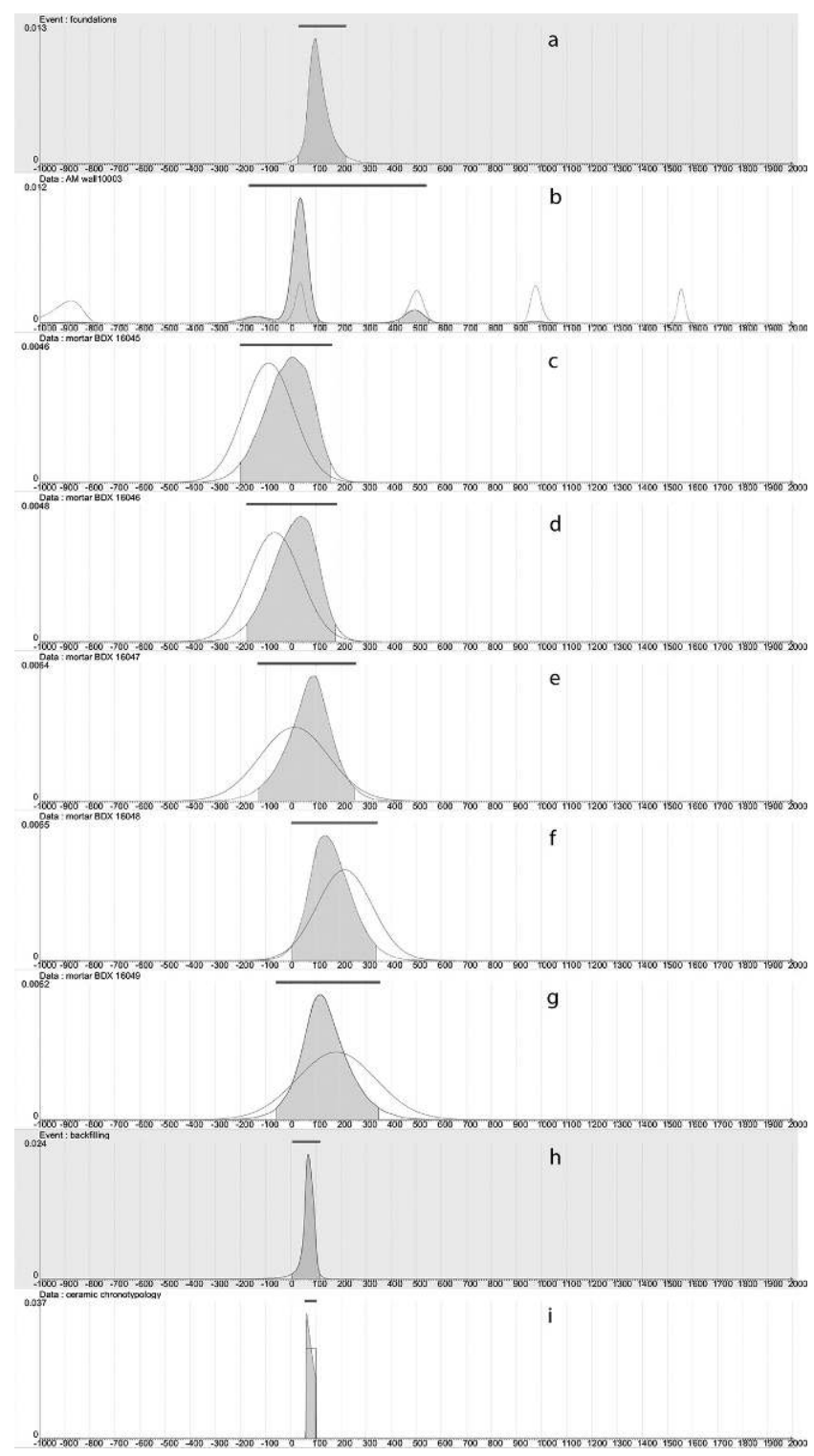


- a priori probability distributions of the dating results which are deduced from the measurements;

- a posteriori probability distributions of the chronological intervals resulting from the combination of all the data.

The analysis shows that between four intervals determined by archaeomagnetic dating (Figure 9b) [-9 B.C., +72 A.D.] is clearly preferred when put in relation with the OSL and the archaeological results. The probability distributions of different mortar samples dated by OSL are overlapping, which indicates good coherence between the individual dating results (Figures 9c-g).

The results indicate that the Grimaldi castle foundations were constructed between 30 and 220 A.D. at 95\% confidence level. The probability distribution (Figure 9a) is not symmetrical due to the chronological constraint imposed by the backfilling of the circular pit (terminus post quem). The probability reaches the maximum at the year 97 A.D. with the median value of 105 A.D. and the chronological interval spreads up to $220 \mathrm{~A}$.D. The upper limit is only the result of the combination of OSL and archaeomagnetic data since no terminus ante quem (apart from the stratigraphic units from $17^{\text {th }}$ and $18^{\text {th }}$ century) that would affect the probability distributions on the right side is known.

In the given context, none of the dating approaches used would have succeeded to date accurately the construction of the castle foundations if they were used separately. For archaeomagnetism, archaeological hypotheses and luminescence dating of mortar enabled to select the most likely chronological interval for the production of bricks. For single grain OSL dating, the archaeological hypotheses and the archaeomagnetic results allowed to validate this new method of mortar dating. For archaeology, the physical methods helped to confirm the initial hypothesis on the construction of the castle foundations. To conclude, thanks to the mutual comparison of the dating results originating from four different approaches, the reliable chronology for the construction of the Gallo-Roman structure whose remains are still visible, as well as the foundations of Grimaldi castle in Antibes could have been established. Our interdisciplinary approach proves ancientness of the standing masonry and attests cultural and historical significance of the monument.

\section{Acknowledgements}

We are grateful to the following organizations which have supported this research financially: CNRS-INSHS [French National Center for Scientific Research - Institute of Human and Social Sciences], Conseil Régional d'Aquitaine [equipment], University Bordeaux-Montaigne [PhD grant and special support for research programs], Mairie d'Antibes. This project was co-financed by the labex LaScArBx [Bordeaux Archaeological Sciences Labex] administrated by ANR [Agence Nationale de la Recherche] with the reference ANR10-LABX-52. We would also like to express our thanks to the Picasso Museum in Antibes (Grimaldi castle) for the sampling authorization.

\section{Bibliography}

Aitken M.J., 1998. An Introduction to Optical Dating. Oxford University Press, Oxford.

Blain S., Guibert P., Prigent D., Lanos P., Oberlin C., Sapin C., Bouvier A., Dufresne P., 2011. Dating methods combined to building archaeology: the contribution of thermoluminescence to the case of the bell tower of St Martin's church, Angers (France). Geochronometria, 38, (1): 55-63.

Chauvin A., Garcia Y., Lanos P., Laubenheimer F., 2000. Paleointensity of the geomagnetic field recovered on archaeomagnetic sites from France. Physics of the Earth and Planetary Interiors, 120: 111-136.

Duller G. A. T., Murray A. S., 2000. Luminescence dating of sediments using individual mineral grains. Geologos, 5: 88-106.

Duller G. A. T., 2008. Single grain optical dating of Quaternary sediments: why aliquot size matters in luminescence dating. Boreas, 37: 589-612.

Galbraith R. F., Roberts R. G., Laslett G. M., Yoshida H., Olley J. M., 1999. Optical dating of single and multiple grains of quartz from Jinmium Rock Shelter, Northern Australia: part I, experimental design and statistical models. Archaeometry, 41, (2): 339-364.

Gallet Y. Genevey A., Le Goff M., 2002. Three millennia of directional variation of the Earth's magnetic field in western Europe as revealed by archaeological artefacts. Physics of the Earth and Planetary Interiors, 131: 81-89.

Goedicke C., 2003. Dating historical calcite mortar by blue OSL: results from known age samples. Radiation Measurements, 37: 409-415.

Goedicke C., 2011. Dating mortar by optically stimulated luminescence: a feasibility study. Geochronometria, 38, (1): 42-49.

Guérin G., Christophe C., Philippe A., Lahaye C., Thomsen K.J., Tribolo C., Urbanová P., Murray A.S., Jain M., 
Guibert P., Mercier N., Kreutzer S. Received dose, equivalent dose, measured dose rates, and implications for OSL age estimates: introducing the Mean Dose Model, in preparation.

Guérin G., Combès B., Lahaye C., Thomsen K., Tribolo C., Urbanová P., Guibert P., Mercier N., Valladas H., 2015. Testing the accuracy of a Bayesian central-dose model for single-grain OSL, using known-age samples. Radiation Measurements, 74: 1-9.

Guérin G., Mercier N., Adamiec G., 2011. Dose-rate conversion factors: update. Ancient TL, 29: 5-8.

Guibert P., Schvoerer M., 1991. TL-dating: Low background gamma spectrometry as a tool for the determination of the annual dose. Nuclear Tracks and Radiation Measurements, 14: 155-161.

Guibert P., Lahaye C., Bechtel F., 2009. The importance of U-series disequilibrium of sediments in luminescence dating: a case study at the Roc de Marsal cave (Dordogne, France). Radiation Measurements, 44: 223-231.

Guibert P., Bailiff I., Baylé M., Blain S., Bouvier A., Büttner S., Chauvin A., Dufresne P., Gueli A., Lanos P., Martini M., Prigent D., Sapin C., Sibilia E., Stella G., Troja O., 2012. The use of dating methods for the study of building materials and constructions: state of the art and current challenges. In R. Carvais, A. Guillerme, V. Nègre, N. Sakarowitch (eds), Nuts \& Bolts of Construction History, Picard, 469-480.

Jain M., Thomsen K. J., Bøtter-Jensen L., Murray A. S., 2004. Thermal transfer and apparent-dose distributions in poorly bleached mortar samples: results from single grains and small aliquots of quartz. Radiation Measurements, 38: 101-109.

Lanos P., 1987. The effects of demagnetizing fields on thermoremanent magnetization acquired by parallel-sided baked clay blocks. Geophysical Journal of the Royal Astronomical Society, $91:$ : 985-1012.

Lanos P., 1994. Pratiques artisanales des briquetiers et archéomagnétisme des matériaux d'argile cuite. Une histoire de positions de cuisson. Histoire \& Mesure, IX, (3/4): 287-304.

Lanos P. 1998. L'archéomagnétisme. In J. Evin, G.-N. Lambert, L. Langouet, P. Lanos, C. Oberlin (eds.) La datation en laboratoire. Paris: Errance.

Lanos P., Kovacheva M., Chauvin A., 1999. Archaeomagnetism, methodology and applications : implementation and practice of the archaeomagnetic method in France and Bulgaria. European Journal of Archaeology, 2, (3): 365-392.

LANOS P., 2004. Bayesian inference of calibration curves, application to archaeomagnetism: Chapter 3. In C.E. Buck, A.R. Millard (eds) Tools for Constructing Chronologies, Crossing Disciplinary Boundaries, Series: Lecture Notes in Statistics, Springer-Verlag, London, volume 177: 43-82.

Lanos P., Philippe A., Vibet M.A., Dufresne P., 2015. User's manual of ChronoModel (version 1.1) [Online]. Available from: [http://www.chronomodel.fr] (Accessed: 3rd May 2015).
Madsen A. T., Murray A. S., Andersen T. J., Pejrup M., 2007. Optical dating of young tidal sediments in the Danish Wadden Sea. Quaternary Geochronology, 2: 89-94.

Medialdea A., Thomsen K. J., Murray A. S., Benito G., 2014. Reliability of equivalent-dose determination and age-models in the OSL dating of historical and modern palaeoflood sediments. Radiation Measurements, 22: 11-24.

Mellinand P., Bats M., D’Ovidio A.-M., Pellegrino E., 2007. Antibes (Alpes Maritimes), Place Mariéjol. Rapport final d'opération de diagnostic archéologique. Inrap, Nîmes, France.

Murray A.S., Wintle A., 2000. Luminescence dating of quartz using an improved single-aliquot regenerative dose protocol. Radiation Measurements, 32: 523-538.

Murray A. S., Clemmensen L., 2001. Luminescence dating of Holocene aeolian sand movement, Thy, Denmark. Quaternary Science Reviews, 20: 751-754.

Murray A.S., Olley J.M., 2002. Precision and accuracy in the optically stimulated luminescence dating of sedimentary quartz: a status review. Geochronometria, 21: 1-16.

PAnzeri L., 2013. Mortar and surface dating with optically stimulated luminescence (OSL): innovative techniques for the age determination of buildings. Il Nuovo Cimento della Società Italiana di Fisica, 36, (4): 205-216.

RHodes E. J., 2000. Observations of thermal transfer OSL signals in glacigenic quartz. Radiation Measurements, 32: 595-602.

Sim A.K., Thomsen K.J., Murray A.S., Jacobsen G., Drysdale R., ERsKine W., 2014. Dating recent floodplain sediments in the Hawkesbury-Nepean river system using single grain quartz OSL. Boreas, 43/1: 1-21.

Thomsen K., Murray A., Bøtter-Jensen L., 2005. Sources of variability in OSL dose measurements using single grains of quartz. Radiation Measurements, 39: 47-61.

Urbanová P., Hourcade D., Ney C., Guibert P., 2015. Sources of uncertainties in OSL dating of archaeological mortars: the case study of the Roman amphitheatre Palais-Gallien in Bordeaux. Radiation Measurements, 72: 100-110.

Urbanová P., Guibert P. A methodological study on single grain OSL dating of mortars: comparison of five reference archaeological sites. Geochronometria, in press.

Wintle A.G., Murray A.S., 2006. A review of quartz optically stimulated luminescence characteristics and their relevance in single-aliquot regeneration dating protocols. Radiation Measurements, 41, (4): 369-391.

Wintle A. G., 2008. Luminescence dating: where it has been and where it is going. Boreas, 37: 471-482. 


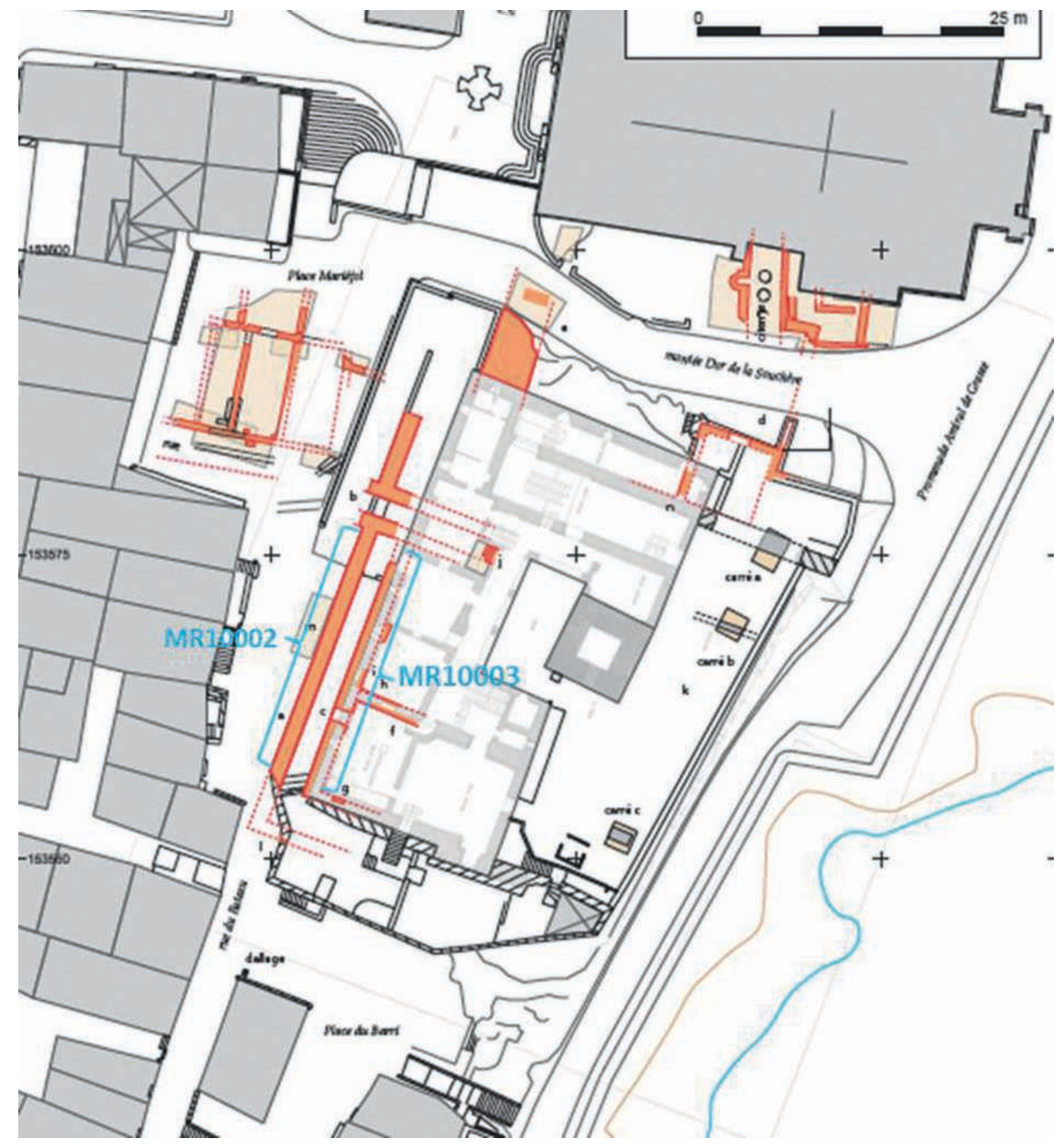

Figure 1 : Petra URbanová et al., Multi-method dating of Grimaldi Castle Foundations in Antibes, France (p. 19)

Figure 1 : Petra URBanovÁ et al., Multi-method dating of Grimaldi Castle Foundations in Antibes, France (p. 19)

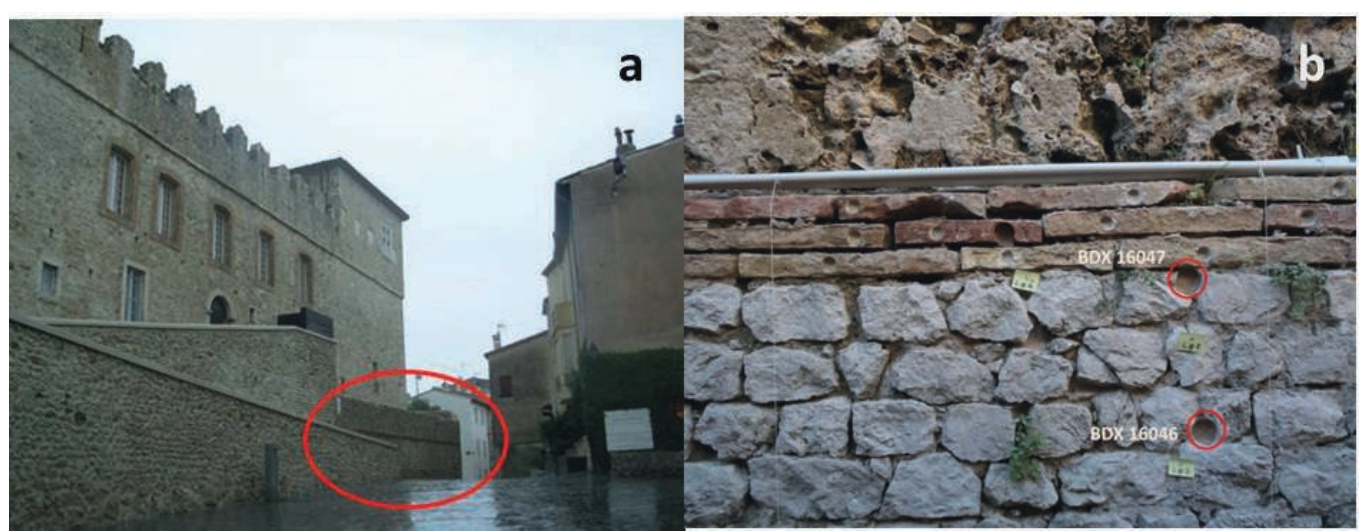


Figure 5 : Petra Urbanová et al., Multi-method dating of Grimaldi Castle Foundations in Antibes, France (p. 24)
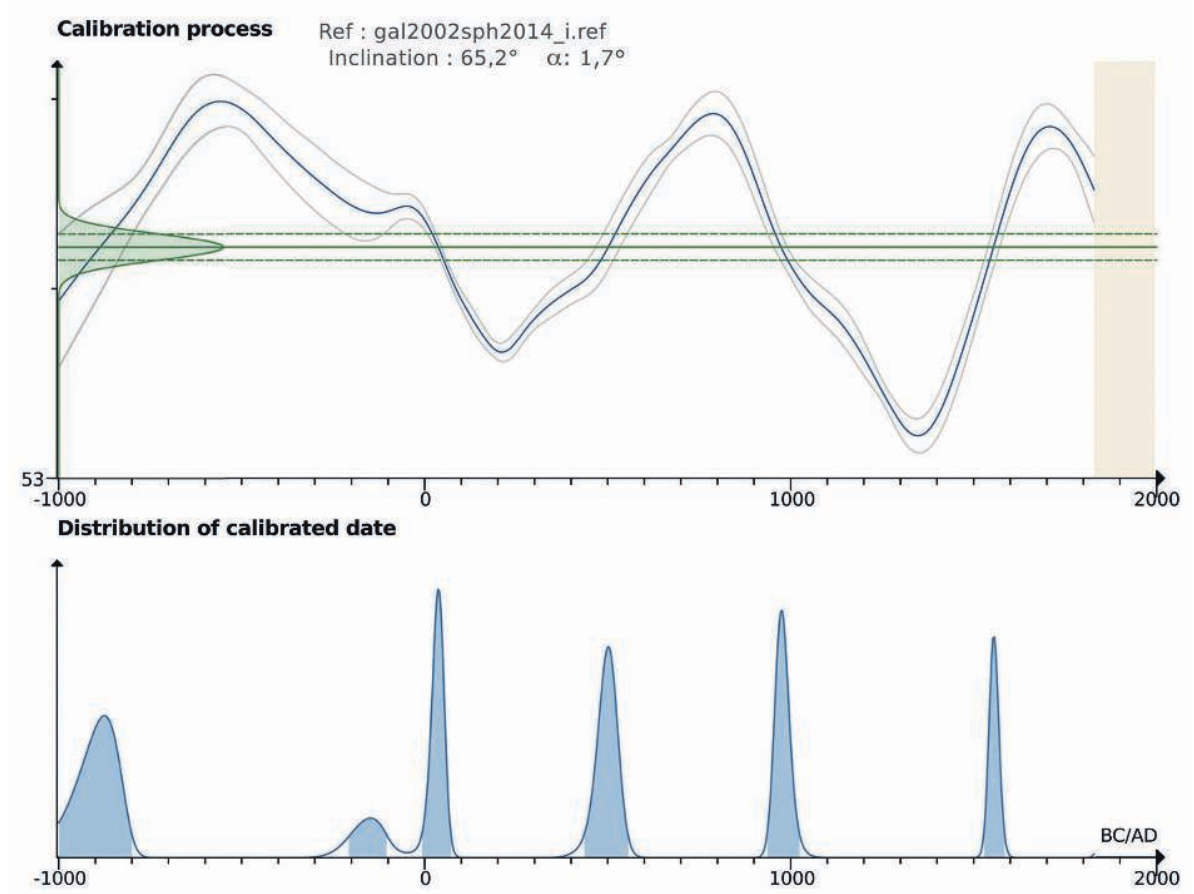
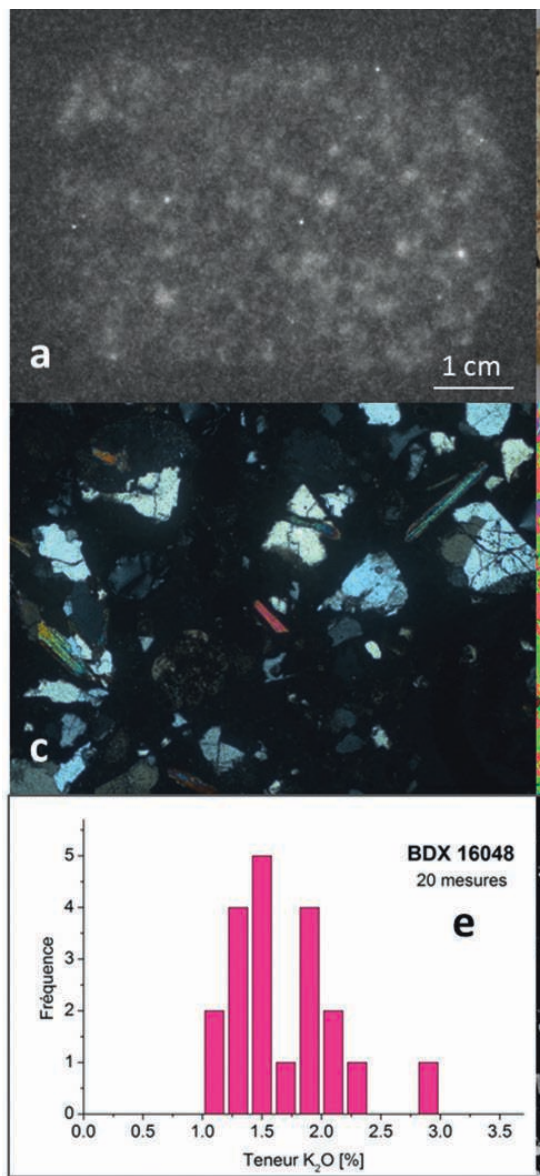

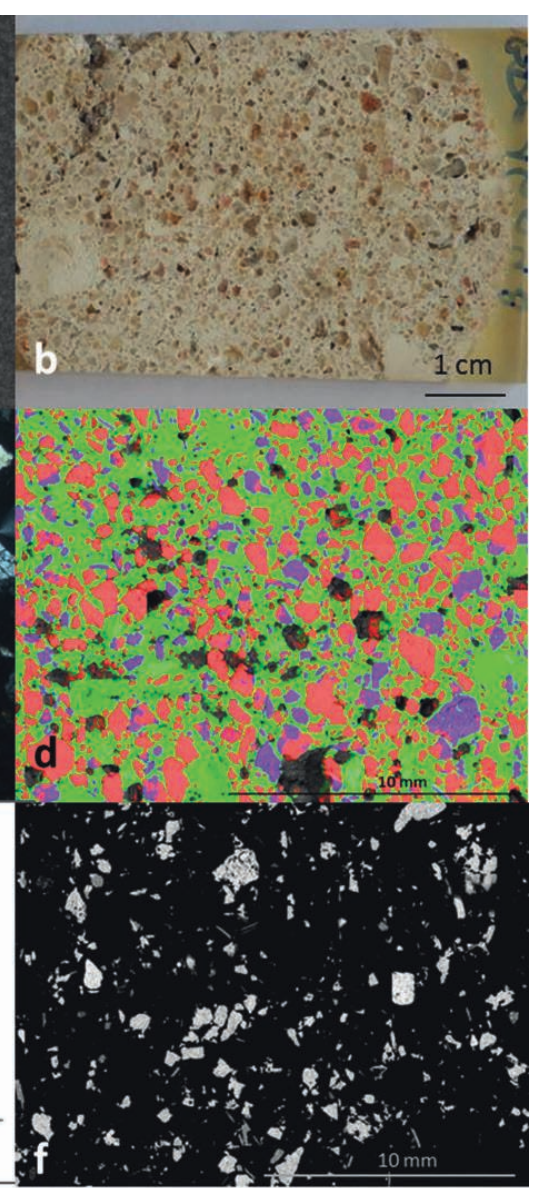

Figure 8 : Petra Urbanová et al., Multi-method dating of Grimaldi Castle Foundations in Antibes, France (p. 28) 


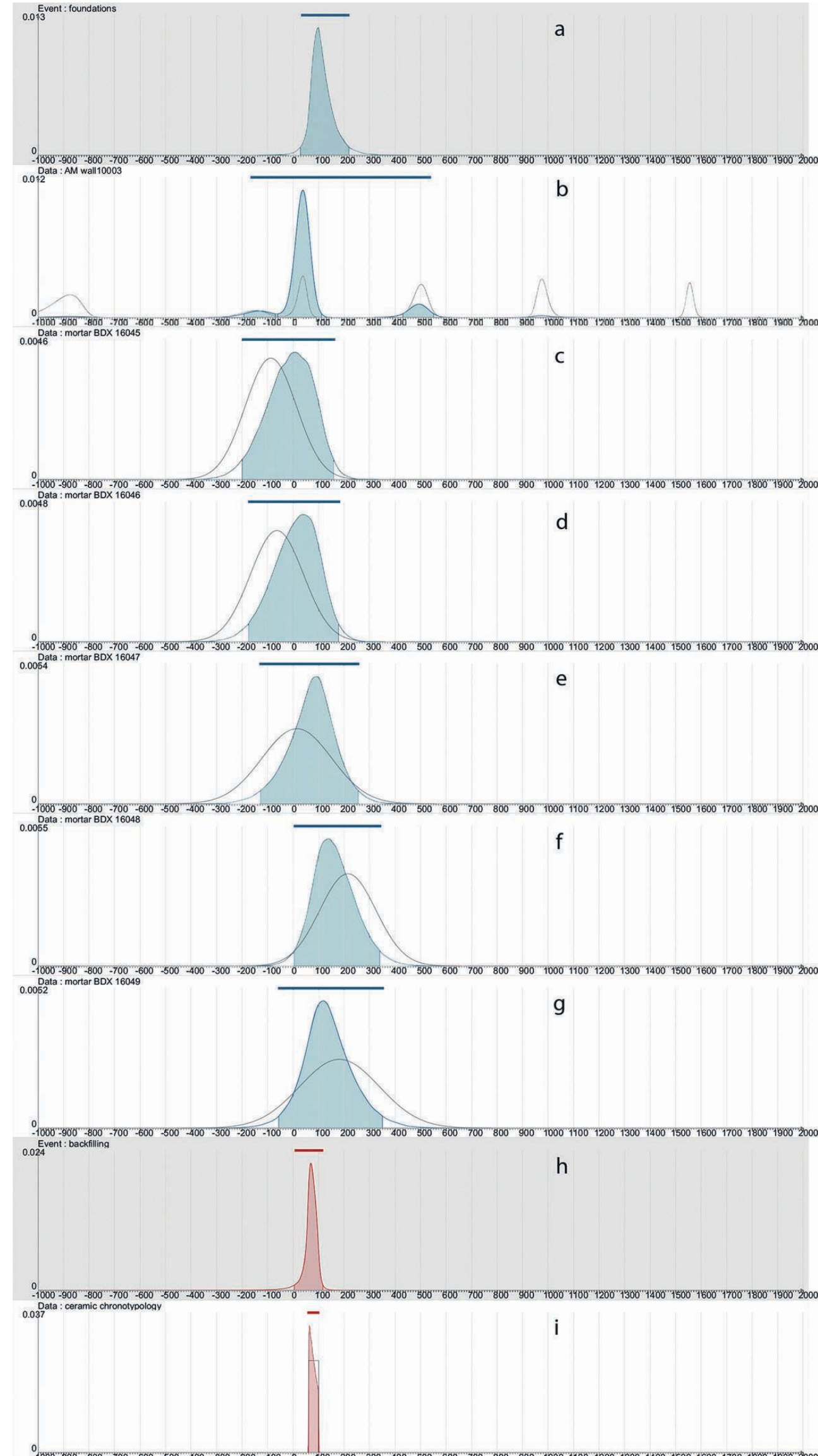

Figure 9 : Petra Urbanová et al., Multi-method dating of Grimaldi Castle Foundations in Antibes, France (p. 31) 